Portland State University

PDXScholar

\title{
Shifting Wetland Policy and Perception in the Columbia Slough
}

Ryan Pemberton

Portland State University

Follow this and additional works at: https://pdxscholar.library.pdx.edu/geog_masterpapers

Part of the Physical and Environmental Geography Commons Let us know how access to this document benefits you.

\section{Recommended Citation}

Pemberton, Ryan, "Shifting Wetland Policy and Perception in the Columbia Slough" (2017). Geography Masters Research Papers. 20.

https://pdxscholar.library.pdx.edu/geog_masterpapers/20

10.15760/geogmaster.21

This Paper is brought to you for free and open access. It has been accepted for inclusion in Geography Masters Research Papers by an authorized administrator of PDXScholar. Please contact us if we can make this document more accessible: pdxscholar@pdx.edu. 
Shifting wetland policy and perception in the Columbia Slough

\author{
Ryan Pemberton
}

Research Paper submitted for partial fulfillment of Master of Science Degree in Geography Portland State University

Approved by:

Advisor

Member

Member

Department Chair

Date: 


\section{Introduction}

On the periphery of Portland, Oregon, at the confluence of the Willamette and Columbia rivers lies an expansive wetland, the Columbia Slough. Once a thriving wetland ecosystem nineteen miles long by three miles wide, the Slough has been drained, filled, and developed into a humanized landscape. The human experience of this landscape has always been about use: people make, move, and exchange things here. Few people actually live and play in this transformed wetland, and most would consider it a featureless, polluted, and otherwise valueless landscape save for the money to be made here. Yet remnants of the old, wild landscape survive in mostly small and fragmented enclaves; they have withstood over a century's worth of human encroachment and pollution. This is the Columbia Sloughscape ${ }^{1}$.

This complex landscape that is both exploited and polluted for commerce, and valued for its natural amenities, has been instrumental to the economic history of Portland. What makes the landscape a good wetland, its large flat terrain near major waterways, also makes it a good place for airports, railroads, highways, and shipping terminals. With good access to transportation and close proximity to Portland, the Slough became an ideal place for industrial, commercial, and agricultural enterprises. The Slough was effectively drained between 1918 and 1921, opening up nearly fifty square miles of this premium real estate. Soon after drainage, the Slough quickly became less of a wetland landscape and more of an industrial landscape, instituting a struggle between natural capital and financial capital.

\footnotetext{
1 "Sloughscape" in this paper refers to the Columbia Slough landscape. It is used to draw attention to the unique qualities of the Columbia Slough landscape, consisting of highly integrated built and natural landscapes, wetscapes, and hardscapes.
} 
The changing landscape of the Slough is a reflection of our changing perspective of wetlands. Once seen as a dark and fearsome mire, the wetland became a redeemable landscape that could and should be drained, and now represents a valued, even treasured, wetland wilderness worthy of preservation. The history of the Slough reflects this changing ideology and the interventions premised in changing visions, transformed from an uninhabited wasteland, to a drained and developed economic pollutoscape, to today's place with protected wild spaces and improved ecological health.

Using the Columbia Slough as a case study, this paper examines how our shifting perspectives of wetlands have influenced the evolution of wetland landscapes. I start by establishing the physical geography of the Slough in order to lay the groundwork for the subsequent landscape discussion. It is followed by review of the existing geographic literature on reading landscapes and the cultural values reflected therein. Then I track the history and development of national wetland management, looking at the cultural, political, economic, and technological factors that all played vital roles in shaping wetland management in the U.S. I follow the arc of federal wetland management policy from endorsement to condemnation of wetland drainage through present day.

Then, using the Columbia Slough as a case study, I demonstrate how the arc of federal wetland policy and perception is reflected in the Columbia Slough landscape. I look at how the Slough landscape changed under drainage and how the local values and perceptions of the Slough have shifted over time just as national policies shifted. I follow that trend through the 1980s when we started acknowledging the Slough as a place to preserve, instituting legally protected wild spaces, regulating water quality, and supporting watershed education. 
I conclude by discussing the recent developments in the Slough's health and the efforts that continue to help restore it. These results and continued efforts are a reflection of how we as a community of Portland-area residents view the Slough. The Columbia Slough Watershed Council has been at the forefront of many of these restoration efforts, engaging and educating the community about the Slough's ecology and the ongoing projects to help improve it. And this is how the landscape is currently changing, shaping the wetland perspective of future generations through education.

\section{The Columbia Sloughscape}

\section{A. Slough in Space}

The Columbia Slough watershed is not a true drainage basin. It is a wetland flood plain of the Columbia River that has been hydrologically severed from the fluctuations of the river by human manipulation. The watershed now known as the Columbia Slough drains fifty-one square miles of land adjacent to the Columbia River, its main channel stretching nineteen miles from the 102-acre Fairview Lake one mile east of the Sandy River mouth to the mouth of the Willamette River (Portland 2005a) (Map 1). Additionally, the watershed includes thirty miles of secondary waterways in lakes and small tributaries (Portland 2005a). The Slough occupies the natural flood plain of the Columbia River, the stream gradient is almost flat and there is little relief across the watershed. Seasonal fluctuations of the Columbia River once cut new channels 
Pemberton 4

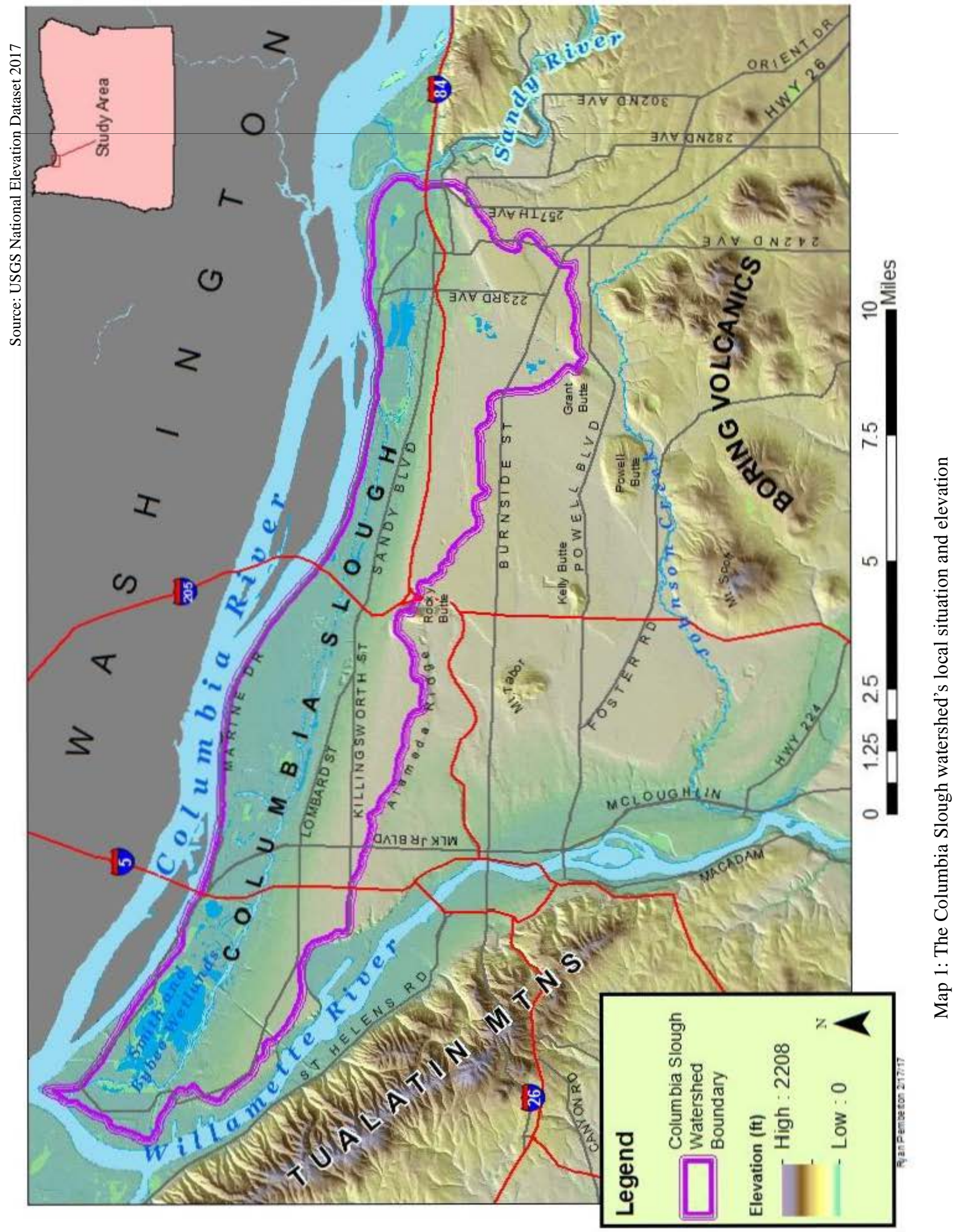


and flooded the wetland, establishing a highly dynamic landscape continually upturning the soils with fresh organic material. Blue Lake, in the eastern part of the watershed, was one of the water bodies that experienced seasonal changes in water levels, but, like Fairview Lake, levees, dikes, and gates now regulate the exchange of freshwater between the river and lakes and along the Slough (Portland 2005a).

With nutrient-rich soils and an aquifer that provides drinking water, the underlying geology of the Columbia Slough basin is an important asset to the region. The bedrock consists of Columbia River Basalts, a relic of multiple lava flows that blanketed much of the region around sixteen million years ago during the Miocene. Then, about ten million years ago, when the volcanoes of the Miocene Cascades were active, mudflows, ash and mixed volcanic debris began to flow into the Columbia River channel. The river carried the debris which then settled across the Portland Basin, extending as far south as the Tualatin Valley and north into Clark County. Today, the Troutdale Formation, with its loosely mixed sand and gravel, has become an important aquifer for the surrounding local communities, including Portland and Vancouver. The formation is deep enough not to be affected by the surface water quality problems in the Slough basin, but is still accessible for groundwater pumping. This formation is also responsible for the watershed boundary along the north shore of Fairview Lake, running between it and Blue Lake to the North, and dividing the lakes into two different basins (Bishop 2003, Orr and Orr 1999). Other important geologic features in the basin include Grant Butte, where Fairview Creek begins. The butte is one of many volcanoes in the Boring Lava Field that emerged during the late Pliocene. Ash and debris from these local volcanoes added another layer of sediment on the Troutdale Formation. Then, from about fifteen to thirteen thousand years ago, the Missoula 
Floods deposited more gravel and alluvium across the region, forming Rocky Butte and Alameda Ridge, making up part of the southern boundary of the watershed. The Sandy River forms the eastern boundary of the Slough watershed, draining a glacier of the same name on Mt.Hood. The sandy sediment found around this river and in eastern parts of the Slough is considered to be a relic of the Mt. Hood lahars that have occurred over the past fifteen thousand years (Orr and Orr 1999).

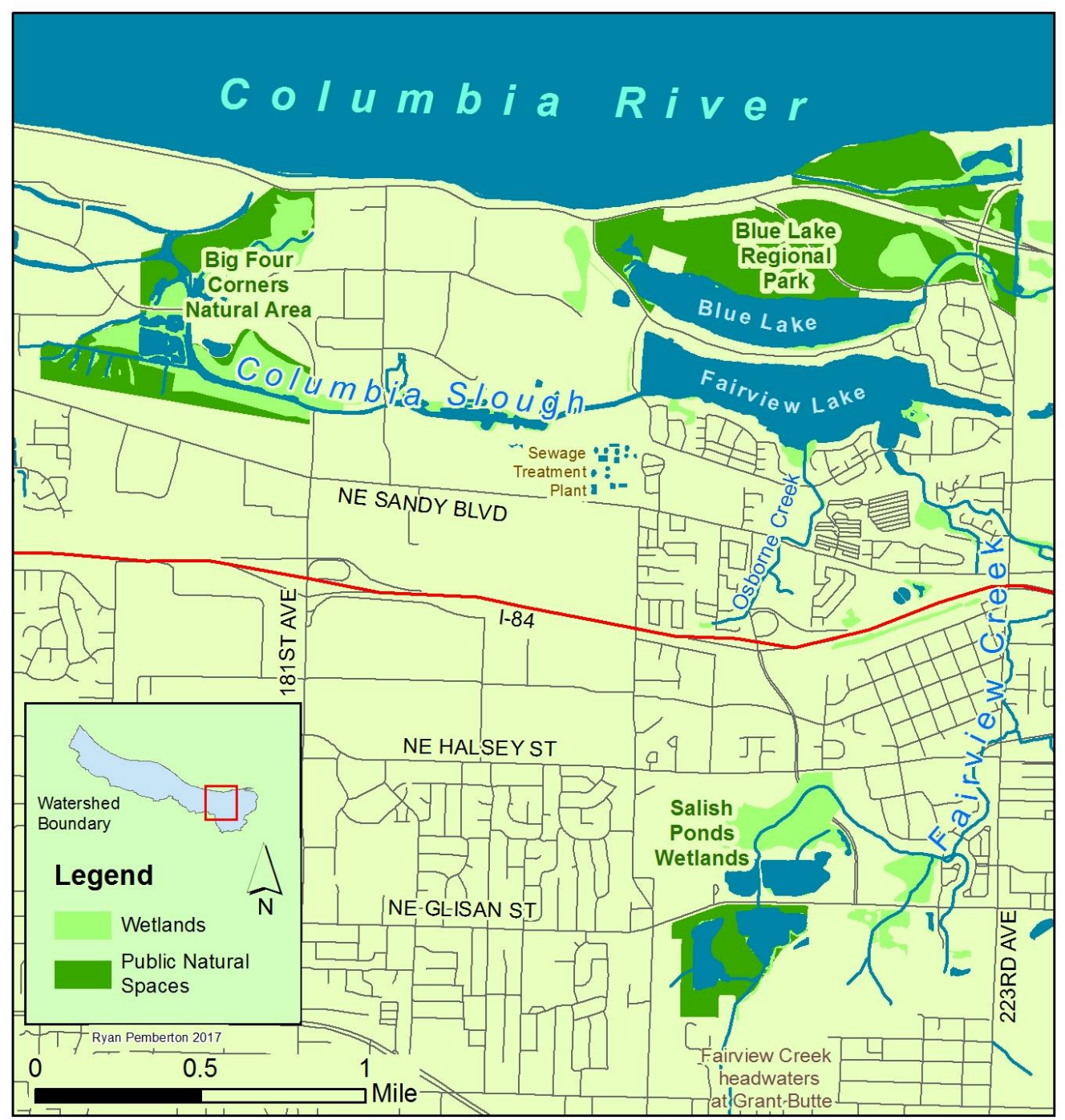

Map 2: Headwaters of the Columbia Slough at Fairview Lake 


\section{B. Hydrology}

Today, Fairview Creek, Wilkes Creek, and Osborn Creek are the Slough's only tributaries (Map 2 and 3). Development in the watershed has effectively put all other tributaries into pipes underground to be discharged directly into the Slough. Fairview Creek is the largest tributary, running five miles from its source at Grant Butte near 182nd and SE Division to its mouth at Fairview Lake. Other tributaries include the tiny Osborn and Wilkes Creeks, entering the main channel of the Slough at approximately 190th and 170th avenues respectively. The watershed also contains many lakes and other small waterways, the largest of which include Smith and Bybee lakes, the Peninsula Drainage Canal, Whitaker Ponds, Fairview Lake, and Johnson Lake. Every body of water in the watershed has a history of severe impacts from human development, and it is only recently that measures have been taken to mitigate some of the damage from pollution and disturbance (Portland BES 2005).

The Slough is hydrologically separated into three segments roughly corresponding with the drainage district boundaries. The upper Slough includes Fairview Lake and all three tributaries downstream for three miles to the Mid-Dike levee at about NE 142nd avenue. The middle Slough extends from the Mid-Dike levee six miles downstream to the Pen 2 levee at approximately NE 18th avenue, where another pump is located. Because of its very low stream elevation gradient, tidal fluctuations and reduced late summer flows can cause the lower Slough to move very slowly or even in reverse, backing up the entire middle Slough. The purpose of the Pen 2 levee pump is to counteract this by pumping the Slough downstream. The lower Slough segment extends from the Pen 2 levee to the mouth nine miles downstream, where the Slough meets the Willamette River. This segment is sensitive to tidal fluctuations of between twelve and 
twenty-four inches twice a day that back up the Slough for miles (Portland BES 2005).

\section{Wildlife and natural spaces}

The Columbia Slough wetland habitat supports many species, including some on the Endangered Species list. bald eagles, willow flycatchers, western pond turtles, and coho and Chinook salmon are among those species listed that spend time in the Slough. In addition, the Slough supports more than 175 species of birds, four species of turtles, twenty-six species of fish, and mammals such as deer, coyote, beaver, and river otter. However, native species

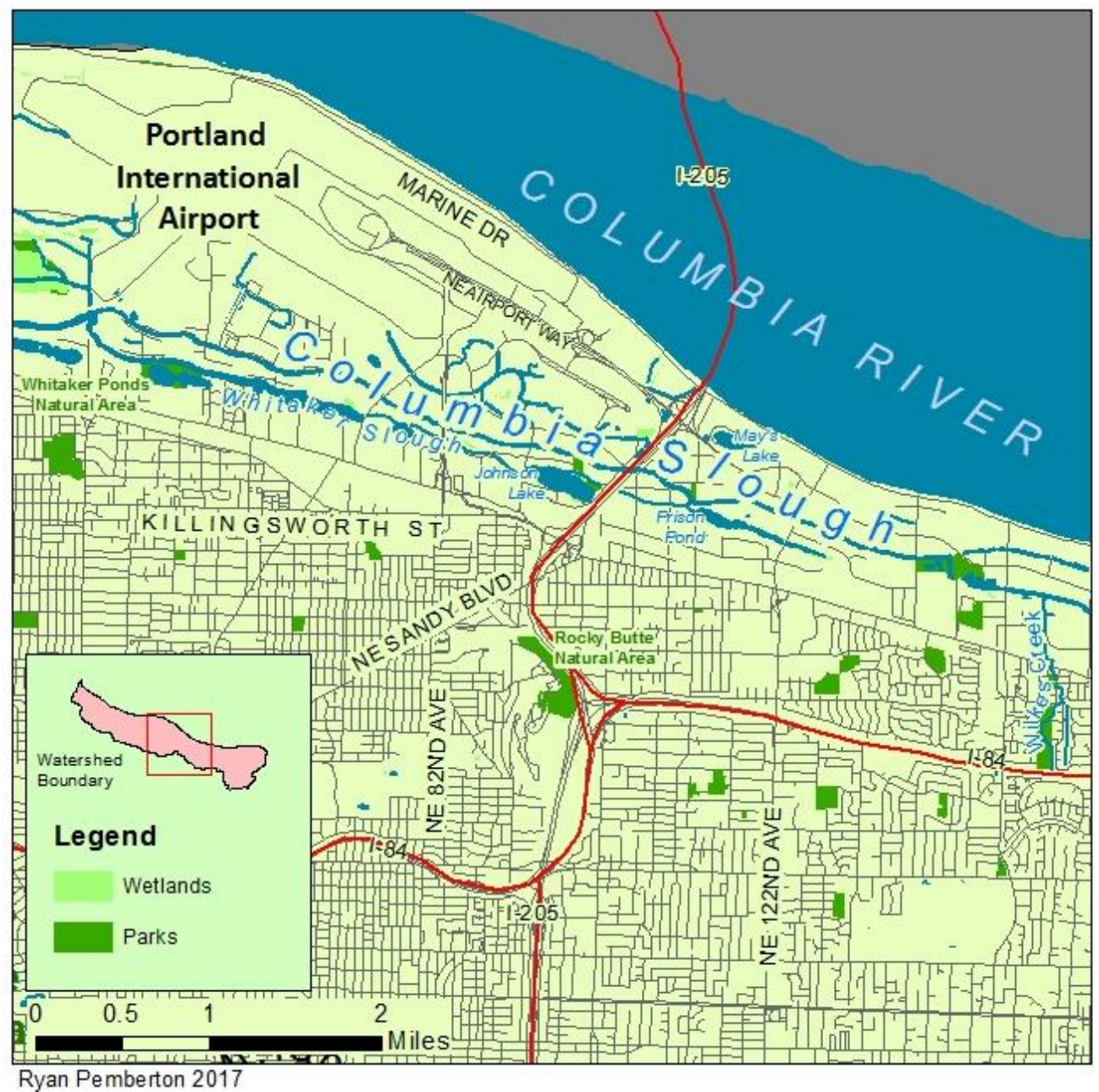

Map 3: The middle stretch of the Columbia Slough extends from Wilkes Creek to Buffalo Slough 
continue to face serious threats of extinction from habitat loss and invasive species encroachment. Few protected natural spaces remain in the Slough for native species to flourish; perhaps the most important of these is the Smith and Bybee Wetland area.

The most prominent natural feature in the watershed, Smith and Bybee Lakes and the adjacent wetland area, is located along the lower Slough (Map 4), and is also one of the largest urban freshwater wetlands in the country at over two thousand acres, supporting a diverse array of year-round and seasonal residents. To underscore the importance of this natural space, Smith and Bybee Wetlands are a stop along the Pacific Flyway, a network of lakes and wetlands from Patagonia to Alaska that provide migrating birds a safe place to rest and recoup along their journey (Houck and Cody 2000).

The native trees and shrubs of the Columbia Slough include black cottonwood, red-osier dogwood, Oregon ash, and Oregon white oak. These are important species endemic to the Willamette Valley ecoregion that can survive in persistently wet soils, such as those in wetlands (Thorson et al. 2003). The once ubiquitous native Columbia sedge and wapato, famously known as a staple food for many local tribes, have been decimated by the arrival of invasive species like Himalayan blackberry, English ivy, and reed canarygrass (Lev et al. 1994). Today, there are few remnant high quality habitats within the watershed, and habitat connectivity is a major concern as commercial and industrial development have fragmented the landscape extensively. Much of the wetlands were drained initially for agricultural use, but industrial, commercial, and residential developments have since been built over the farms. This development has effected a landscape with very little open space or wetland habitat for the native species.

The general decline of ecological health in the Slough stems almost entirely from one 
thing: poor water quality as a result of development. When the entire watershed thrived with healthy populations of native species, the Columbia River flood waters would provide seasonal freshets that would flush the wetlands with fresh clean water. The native flora and fauna thrived under these conditions that relied on seasonal fluctuations of water. When the first levees were built in the Slough around 1920, the seasonal water regime that this robust ecosystem relied on was drastically altered. By channelizing the Slough, building levees, and draining the lowlands, the watershed could then be developed, paving nearly all of the twenty-five square miles of former wetland. The surrounding urbanized areas, in turn, drained their surface runoff into the Slough, compounding the effects of the disrupted water regime.

The Columbia Slough is a complex landscape that has had a long history of human occupation and exploitation. At first glance, it may appear a derelict space whose greatest use is a thoroughfare for people and goods traveling to another destination, a "fly-over" landscape. But a closer examination tells a story of a once-thriving ecosystem that was dehydrated and suffocated by asphalt and concrete. The drainage of the Slough, and subsequent decline of the landscape, was the result of a half-century long battle between the federal government and wetlands. The next section lays out how the United States administered, organized, and 
Pemberton 11




subsidized the drainage of wetlands, contextualizing the drainage of the Slough at the national level.

The Slough is a landscape of utility, as the majority of the watershed is privately owned and non-residential (Metro 2010). Furthermore, an expansive industrial sanctuary exists in the center of the watershed, regulating land use to preserve industrial development. But how did this once thriving wetland become a literal sanctuary for pollution, or, alternatively, how did this once undevelopable landscape become a regional economic hub? This paper looks at the historical evolution of the landscape, in the context of national wetland management, to examine how shifting cultural values and geography have forged the Columbia Slough landscape seen today.

\section{Literature review}

Geography provides a framework to understand this transformation while considering the many facets and contributing forces to the changing landscape. The idea of landscape interpretation within Cultural Geography examines the transformations and meanings of landscapes: how they evolved, how they function, and what they mean to different groups of people (Meinig 1979). This paper uses this framework to interpret the Columbia Slough landscape in its historical context.

\section{Landscape}

Looking at where the idea of landscape originated, Denis Cosgrove and Stephen Daniels trace it back to the Italian Renaissance, where they define landscape as a way of seeing and as a 
representation of power (Cosgrove 1984; Cosgrove 1985; and Cosgrove and Daniels 1988).

They argue that the idea of landscape was borne out of landscape painting, linking the development of the landscape idea to the development of modern capitalism through the “practical appropriation of space" (Cosgrove 1985, 46). Landscape painting works to create a "visual ideology" of real life, suggesting a one true way of seeing. Furthermore, the powerful and wealthy were the only ones that could afford to commission an artist to depict a landscape, thus establishing the concept of landscape as something only controlled and accessed by the powerful (Cosgrove 1984; Cosgrove and Daniels 1988; Mitchell 2000).

With roots in Sauer's "Morphology of Landscape" (1925), reading the landscape as a book "authored" by culture was first made explicit by Peirce Lewis (1979) and Donald Meinig (1979; Mitchell 2000; Schein 1997). In his “Axioms for reading the landscape,” Lewis writes that "Our human landscape is our unwitting autobiography, reflecting our tastes, our values, our aspirations, and even our fears in tangible, visible form" $(1979,12)$. This concept of landscape, however, drew criticism from those who thought it too simplistic a model, the leading voices of which one James Duncan and Nancy Duncan (1988; Duncan 1990; Barnes and Duncan 1988). They thought the metaphor needed to be deepened, that geographers needed to examine how landscapes "encode" the information in the landscape, and consider how power relations shape and control the interpretation of the landscape (Schein 1997).

Duncan and Duncan (1988) argue that reading the landscape is something that we all do, experts and laymen alike who go about their ordinary day, each interacting with and changing the cultural landscape, however imperceptible, while also being a part of it. This is what they refer to as "intertextuality," where "the context of any text is other texts" (Duncan 1990, 4). The 
cultural landscape is a living thing that changes continuously, and everything is a text that can be read and reshaped in our everyday cultural practices (Schein 2009).

Citing Lefebvre (1991), Mitchell (2000) discusses the shortcomings of the landscape-astext metaphor, noting that most readers may be reading the same material landscape but be reading radically different texts based on their own tastes, values and fears. Hence, the process of reading the landscape as text "runs the risk of reducing the lives and experiences to merely the thought" (Mitchell 2000, 123). Mitchell (2000) concludes that "landscape is best seen as a force in, and place for, the social reproduction of society" (144), and that "like culture, [landscape] seeks to regularize and naturalize relations between people" (144). However, despite his critique of Lewis's landscape metaphor, Mitchell (2000) agrees that history is a crucial factor in understanding landscape (145).

The Columbia Slough landscape does this through its complex and integrated network of built and natural environments. The entire Slough has been a contested space since the building, establishment, and peopling of the Portland area, beginning around the 1830s (Abbot 1999). And the current complex of land uses and ideals is the product of over a century of shifting cultural values encoded in the landscape. This paper aims to examine the causes of these shifts, and to look at how the landscape works to serve those cultural ideals.

In Lewis's “Axioms for reading the landscape" (1979), he highlights the importance of understanding the history of a landscape in order to more fully understand the landscape itself. He breaks down this examination into two parts: "The corollary of historic lumpiness," and "the mechanical (or technological) corollary." "Historic lumpiness" refers to the knickpoints, or points in time that can be referred to as causing significant change in history where significant 
cultural change is provoked by wars, depressions, and major inventions. Eras of common cultural values are "lumped" together, their boundaries in time somewhat discretely defined by knickpoints. The major knickpoints in the history of drained wetland landscapes include legislation (Swampland Act, Clean Water Act, etc.), technological advances (tiling, steamengine, etc.), and societal stressors (floods, wars, depression, etc.).

Lewis's "mechanical corollary" underscores the importance of understanding specifically how the landscape works and has changed over time. He writes that understanding this is crucial to the understanding of the landscape as a whole. I apply this in my analysis of the Columbia Slough landscape, looking specifically at how the landscape operates: the drainage districts, major industries, people, and natural environment.

\section{Place}

Cresswell (2015) discusses the difference between "place" and "landscape" as the duality of being inside and outside of an environment. He writes that landscapes are to be observed from the outside, and places are to be lived in. Similarly, Tuan (1977) defines "place" as the destination to which you travel through "space" to arrive; space is the area between places. The Columbia Slough is both space and place, and is many different places to many different people. For many thousands of people, it is where they work, making their livelihood to support themselves and others. For others, the Slough is where they fish, despite the health risks, because it is a place that reminds them of their home in another country (Profita 2012). And for the countless others who arrive and depart daily from Portland International Airport, the Slough is a place with a multitude of different meanings. However, while the idea of place is near that of 
landscape, and is certainly a subject worth studying in the Slough, this paper is not about the assembly of places that constitute the Slough. It is about how the landscape has evolved with and to be a representation of the dominant culture in the Slough, that is, of course, the culture of those who own and control the landscape.

The experience of landscape is built on the reconciliation of one's perceived environment with their own knowledge and memory of the place (Tuan 1974, Meinig 1979, Lewis 1979). As culture changes, so do perception and perspective of the landscape, which can then usher in a change of the landscape. This concept, in the context of wetlands on a regional scale, is the subject of Hugh Prince's book, Wetlands of the American Midwest: A Historical Geography of Changing Attitudes (2008). Prince tracks the changes in peoples' perception of wetlands through history and how the management of wetlands in the Midwest changed relative to perception. He covers the history of wetland occupation, use, and management across six Midwestern states over 300 years. Prince discusses how Native Americans, fur-trappers, farmers and industrialists, and modern recreationists have each had a nuanced perception of wetlands, and how that shift in dominant cultural values has influenced the shape of the landscape.

Others have written about the landscape history of Portland and the surrounding area (Lang 1999; Abbot 1999; Robbins 1999; White 1995), but the scales of these studies are larger than what is being discussed in this paper. The cultural landscape of the Columbia Slough is separate from that of the surrounding metropolitan region because it is rooted in a history of wetland drainage. Historically, the landscape was the last area near the city to be developed because of its inaccessibility as a wetland (Abbot 1999). Now, because of drainage, the watershed is almost entirely developed, a veritable landscape of industry, economy, and 
transportation.

Stroud $(1995 ; 1999)$ writes on the environmental and social history of the Columbia Slough, focusing on the theme of environmental injustice. Stroud discusses how minorities were disproportionately affected by the pollution caused by the Peninsula Industrial District, and that the city was not doing enough to mitigate it. I refer to Stroud's work throughout this paper, particularly in the discussion of Vanport.

This paper is structured around the idea of reading the landscape through its historical context. I examine how wetland policy and perception has changed over time at the federal level, and then look at how those same patterns are observed in the Columbia Slough. Reading the Columbia Slough landscape in this context is essential for understanding how the it became what it is today and the direction it is heading for the future. This research has implications for planners, students of wetland geography, and city officials who are looking to gain a greater understanding of this complex landscape.

\section{Wetlands in America}

The landscape of the Columbia Slough is rooted in the larger history of wetland management in America. Native Americans had been altering wetland landscapes long before Europeans arrived through controlled fires, logging, and the cultivation of wild foods (Cronon 1983; Pyne 1982; Denevan 1992). This paper, however, will focus on the evolution of wetland management from a governmental perspective. For a discussion of wetland management in the pre-Columbian period by geographers, see above.

Since the mid-nineteenth century, the U.S. government tried to implement strategies to 
convert wetlands into developable land. To achieve this, large and small scale drainage projects were implemented to carry water away from saturated soils, making them dry enough to build structures and raise crops. The drainage district was the governing body created to administer the drainage projects in a given watershed. As the organizational structure, funding, and power of the drainage district evolved over the latter half of the nineteenth century, so did the technology used to physically alter the landscape. These factors culminated in the early twentieth century with new legislation allowing drainage districts the physical and political tools to drain wetlands, catalyzing the drainage of the Slough in 1918.

\section{A. Agrarianism and the early American land ethic}

Agrarianism was a dominant theme in early American culture and played a critical role in the rhetoric surrounding wetland drainage legislation. Inspired by Thomas Jefferson, agrarianism is considered to be a value intrinsic to the very identity of America. Under agrarianism, the independent and land-based ideal of farming stood for virtue and health, and the farmer was considered a pillar of the community, to be respected based on his apparent morality evidenced by his honest and hard-working lifestyle (Danborn 1991). Early American agrarianism fostered a land ethic that held farming as the highest and most important use of land, and land that was not working was being wasted (Malone 1993). Hence, wetlands, with their saturated soils and inaccessibility, drew the ire of many.

The Romantic Period of the early nineteenth century accentuated these tenants of agrarianism by glorifying natural landscapes, painting beautiful scenery as heavenly places. And although they were natural landscapes, wetlands were not painted in this same light. As 


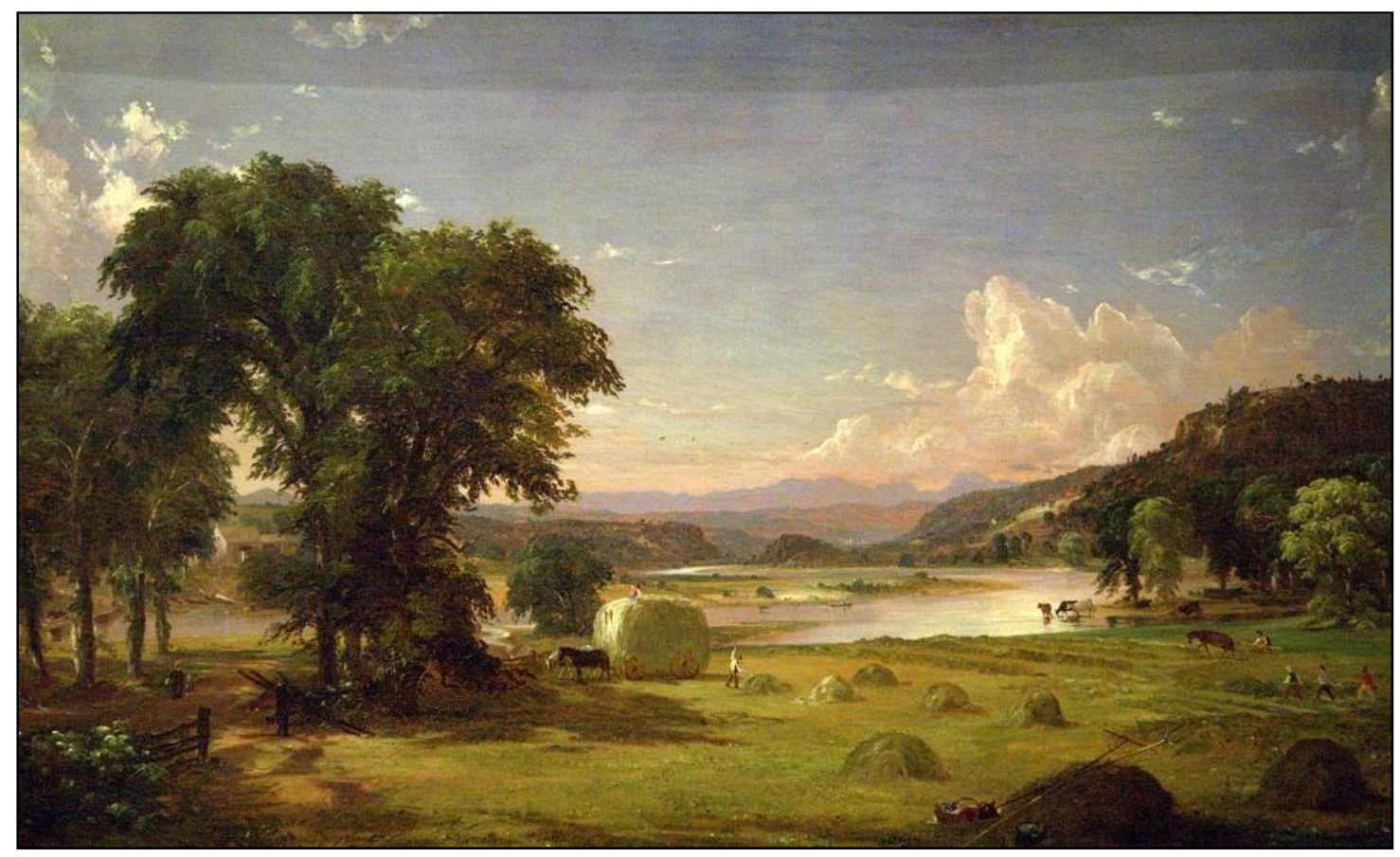

Fig 1: Cropsey, Jasper. Haymaking. 1853

Cosgrove and Daniels (1988) discuss, landscape painting was an expression of power and control over the natural world, depicting a true way of seeing nature. During the Romantic period, picturesque landscapes were glorified and unknown, unproductive landscapes like wetlands were demonized (Figs. 1 and 2). The farm and range lands stood for all that was good, holy, and safe, where all of those agrarian ideals could be exercised and pursued. The swamps, however, stood for the dark, mysterious, and evil places where disease and dangerous creatures resided, an impenetrable mire, and, for all intents and purposes, the Hell to their pastoral Heaven (Bunce 1994; Miller 1989). Tuan (1977) writes "Myths flourish in the absence of precise knowledge" (85). In the case of wetlands in the nineteenth century, their demonization is linked to their inaccessibility, and that stigma begins to dissolve around the turn of the century as wetlands are drained. 
With the newly acquired 1803 Louisiana Purchase, 1845 Texas Annexation, 1846 Oregon Territory, and 1848 Mexican Cession, the federal government found itself with more than twice as much land as it had in its first thirty years of existence (Meinig 1995). Land disposition became a top priority and the federal land disposition program began in 1812 with the creation of the General Land Office to oversee all of the unclaimed public land, the "public domain" (Meinig 1995). Made famous for the Homestead Acts of the 1860s and 1870s, the land disposal programs refer to many pieces of legislation that transferred ownership of public domain land to states or individuals to manage, sell, live on, or make any productive use of. These agrarian values would be codified specifically for wetlands in 1849 with the passage of the Swamplands Act, a land disposal law, focusing on the conversion of wetlands to economically viable land,

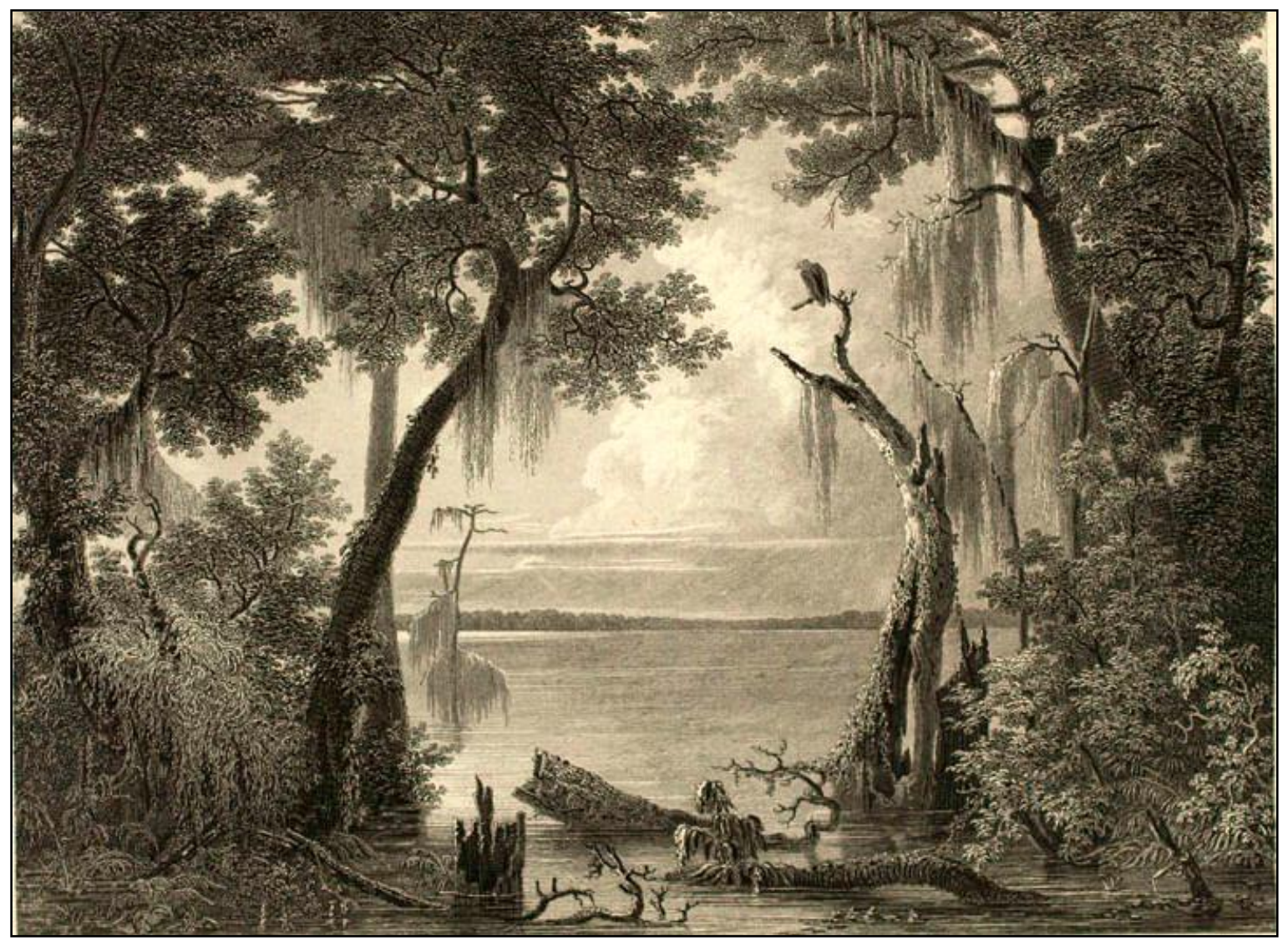

Fig. 2: Chapman, John Gadsby. Lake of the Dismal Swamp. 1842 
primarily for cultivation (McCorvie and Lant 1993).

\section{B. Passing the first wetland drainage legislation}

With flooding becoming more of a problem due to the unilateral increase of industrialization, farming, and population, people sought a scapegoat in swamps. According to the American government of the 1840s, swamps were underused spaces where stagnant waters and saturated soils restricted human progress during an age where westward expansion and manifest destiny were the American prerogative (Prince 1997; Meinig 1995). Draining the swamps was considered a solution to make the land more conducive to development while presumably reducing flood risk.

Federally endorsed wetland drainage started with the Swamp Land Act (SLA) of 1849. Louisiana was the first and only state affected by the initial law, which included public land that was not arable and therefore not suitable for the federal land disposition programs administered by the General Land Office created that same year. While the land disposition programs encouraged people to move out west, the SLA simply transferred ownership of the swamp lands to the states, which would then theoretically sell the land to the public with the intent to build levees and then drain the land, making it arable and habitable (Beauchamp 1987).

\section{Defining "Swamp"}

The following year, twelve other states were granted land in the Swamp Land Act (SLA) of 1850 that were considered "swamp and overflowed lands made unfit thereby for cultivation" (Bogue 1959, 46). The legal definition of a swamp then as now is an ambiguous and imprecise 
one, as most wetlands may or may not have visible surface water and may only be seasonally wet. Even today, wetlands are officially defined somewhat ambiguously, as evidenced by this definition from the Clean Water Act that is used by most government agencies: "wetlands are those areas that are inundated or saturated by surface or groundwater at a frequency and duration sufficient to support, and that under normal circumstances do support, a prevalence of vegetation typically adapted for life in saturated soil conditions" (Clean Water Act of 1972). The current definition still focuses on the saturation of soils, and frequency of inundation, coupled with a suite of other environmental factors including topography, drainage, and fauna. The biggest difference between our current definition and the one provided in the initial SLA is that we have much more accurate means of measuring soil types and saturation, and more data to support inundation frequency and soil saturation trends, allowing us to quantify precise characteristics of a wetland.

Aside from the definition of "swamp", the term itself brought about significant discussion in Congress. Swamps were held in low regard, and the passing of the SLA was the grand stage for congressmen to verbalize their fears and grievances against swamps to formally endorse a congressional act to rid the country of them. For example, senators in the lower Mississippi basin associated swamps with flood damage and dangerous health effects, calling them "generative and noxious influences," "injurious to human health," "fever and ague lands," “pestilential," and "prolific of disease and inflicting of a curse" (Vileisis 1997, 74). Then, unfamiliar with the Mississippi Valley, Connecticut Representative Chauncey Cleveland argued that overflowed lands were fertile and excellent for growing crops. He thought the SLA gave away too much good land (Cowdrey 1971). Missouri Senator Thomas Hart Benton furthered this 
notion by describing swamps as "a refuge for wild animals that prey upon the stock of the people of the country," and that they "acted as impediments to progress of the people in the going from one part to another" (Vileisis 1997, 75).

Not only did swamps directly impede the working of the land with their impenetrable saturation, but they also impeded economic progress by blocking access to markets (Cowdrey 1971). As discussed in reference to the Columbia Slough later in this paper, drained wetlands make for great transportation corridors by offering flat terrain near shipping routes. Thus, wetland drainage removed barriers and opened up highly accessible land for agricultural and industrial development and transportation.

The SLA would pass in 1849, but not without Louisiana Senator Solomon Downs (Fig. 3) explaining how wetland drainage could exacerbate flooding downstream, "It is reasonable to suppose that the whole country is now more rapidly and thoroughly drained into the Mississippi than when in a state of nature. Then no doubt, a great quantity of water was collected in pools and swamps, and there remained until carried

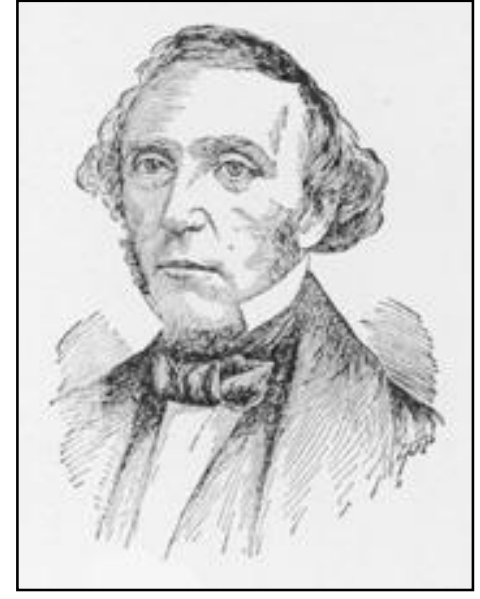

Fig. 3: Louisiana Senator Solomon Weathersbee Downs by gradual evaporation" (Terry 1935, 45). He referenced Charles

Ellet Jr. (Fig. 4), a civil engineer who was notorious for not cooperating with government projects, earning a reputation as an argumentative rabble-rouser. One of Ellet's theories described the negative watershed-scale hydrologic effects of development, urbanization, and levees, and acknowledged the reduction of wetlands and natural spaces as water holding and flood mitigating resources (Lewis 1968). 
Ellet's theories on flood control correctly explained how the most effective flood mitigation is concerned with slowing the water down so it is not all in the river at the same time. This is achieved by sequestering the water temporarily in wetlands and natural spaces that have small water bodies and a soil profile that retains moisture well. Ellet's theories would fall on deaf ears for over a hundred more years until federally subsidized drainage projects would cease in the 1950s.

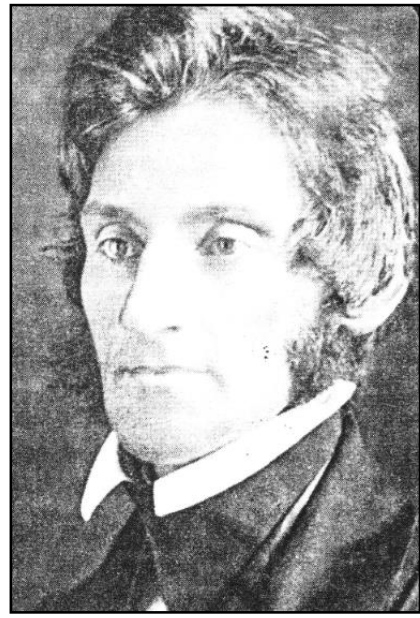

Fig. 4: Charles Ellet Jr., c. 1850

After Downs explained Ellet's theories on river hydrology, arguing against levees as effective flood control, Congress proposed more levee building and drainage to prevent flooding downstream. The initial swamp land bill pertained only to Louisiana and easily passed Congress in March of 1849. Thirteen more states would be granted land under the SLA the following year, and Oregon would wait until 1860 for their own drainage legislation (McCorvie and Lant 1993). But the larger discussion of what to do with the vast amounts of federally held wetlands had begun and the whole country was interested in states becoming more prosperous by converting wetlands into arable, developable land.

Senator Downs was alone in Congress in his fight against wetland drainage. Several other congressmen had as much to say as Senator Downs, but in support of drainage. Three main reasons emerged from those hearings, resulting in the passing of the law (Beauchamp 1987):

1) Wetland soils could not support agriculture or structural development, making them economically unviable, and inaccessible.

2) Malaria was associated with wetlands, and thus drainage was thought to benefit 
public health.

3) Draining wetlands removed barriers and created farmland with excellent accessibility.

\section{Drainage Districts and The Louisiana Experiment}

In 1852, the Louisiana state government began giving structure to the new wetland disposition program. This was done by creating drainage districts to govern topographically and hydrologically similar regions. Districts fitting the established definition of "swamp" were subject to the Swamp Land Act (SLA) disposition program and each unit was responsible for its own levees. As the nation was going through serious growing pains with the newly acquired West expanding the country's area by two-thirds and a civil war looming, this was a new style of increased governmental oversight over a new and strange jurisdictional boundary (Strausberg 1977).

The districts were administered by Boards of Swamp Land Commissioners who each oversaw drainage and reclamation in their own district. The revenue from selling the granted swampland went to the board, who would then collectively decide which projects were most critical. Then the board would hire the lowest bidding contractor and see that the projects were completed. The most urgent projects took precedence, and usually involved the repair of existing levees (Harrison 1951). In theory, this seemed like a straightforward and simple process, but the administrative and technological learning curve proved to be steep as fraudulent land dealings and engineering shortfalls plagued the program from the start.

There was a fundamental lack of hydrologic and engineering expertise that resulted in levees being built too close to the river, with an undersized base, or with inadequate material that 
eroded quickly. Furthermore, members of the board representing their districts conflicted in their fundamental approach to how swamp lands should be reclaimed. For example, some commissioners insisted on building big solid levees to force the river to downcut and expedite the water downstream, while others felt that a system of drains and distributary bayous was the best approach to controlling flooding. So often a mix of both or some other approach was used, often coupled with unsound engineering, resulting in an ineffective and/ or poorly executed flood control solution, leaving the land behind the levees still inaccessible to farmers and developers (Harrison 1951).

The boards of commissioners were susceptible to persuasive landowners lubricating the process in their favor, showing preference in the projects they chose and the expediency with which they were completed (Hewes and Frandson 1952). Generally, progress was slow, partially because seasonal flooding often limited the window for construction to the summer months, and in cases of malarial outbreaks, laborers willing to work on the levees were hard to find; however, many complained about the slow pace with which the Board worked to decide on projects, contractors, and budgets (Cowdrey 1977). Additionally, the board fell under scrutiny when audits revealed poor accounting records and questionable purchases, with one auditor calling a recently purchased piece of dredging equipment "an extravagant piece of furniture" (Harrison 1951, 39). Then when the Board went to sell the equipment, they cut into a secure levy to get it out of the canal it was in, and with the boat removed, they realized the funds were not available to fix the levee properly. The soft spot in the levee that remained later caused a breech and extensive damage to the neighboring landowners' property (Harrison 1951). Because of scandals and inefficiencies like these, drainage districts quickly fell into disrepute after their creation. 
Clearly over their heads in what proved to be a complex and difficult position managing the drainage districts, things remained unchanged for several years. The Board was building and maintaining levees for flood control, and only tenuously accomplishing it at best, as big floods in 1856 and 1858 severely hampered many early projects. The 1858 floods wiped out $20 \%$ of the state's sugar crop, with many of the levees incapacitated by the floods two years before (Sitterson 1953). After that, the Board made plans to build more levees, closing off more wetland territory assuming they would still help control flooding. These plans were opposed by State Engineer Louis Hebert who contested that keeping some wetlands in a natural state was important to the state's flood management plan, echoing the sentiments of Ellet nine years earlier. The Board argued that their funds were appropriated with the primary purpose to protect from flooding and that levees were the best way to accomplish that. The state legislature and public agreed with the Board, so once again the "levees-only" policy persisted (Harrison 1951).

Despite their apparent inadequacies, the people of Louisiana wanted even more out of their Board of Swamp Land Commissioners. They cited the SLA saying that the state was supposed to facilitate drainage of the wetlands, rendering the land not just protected from floods, but also arable and safe for construction so landowners could better use the land that they paid for (Cowdrey 1977). The demands on the Board far exceeded what they had been able to accomplish in the first decade of their existence, and little progress would occur over the next decade during the Civil War. With the war consuming many of the state's resources, work on flood and drainage projects ground to a halt during the 1860s. In just Louisiana, more than 107 miles of levees were destroyed during the civil war (McCorvie and Lant 1993)

Outside of Louisiana and the lower Mississippi in the Midwest, wetlands were managed 
slightly differently. Glaciers from the last ice age left much of the Midwest flat and poorly drained, resulting in many wetlands throughout. In much of Indiana and Illinois, Europeanamerican settlements predated the federal swampland grants, and in many cases farmers reclaimed wetlands themselves by digging ditches and building dikes (Prince 1997). This was done so extensively that in 1845 , when swampland legislation was being discussed nationally, an Indiana farm journal wrote that "many farmers have already more arable land than they can till to advantage" (quoted in Strausberg 1977, 192), implying that no drainage assistance or legislation was needed in Indiana. But with the 1850 Swampland Act, along with several other Midwestern states, Indiana and Illinois were granted 1.3 and 1.5 million acres of swampland, respectively (Prince 1997). Indiana's administration of their granted swamplands differed slightly from Louisiana's, but as was the case for all of the original 1850 swampland grant states, the result was the same: the state government attempted to form some administrative body, such as a drainage district or swampland commission, then, due to lack of oversight, corrupt board members, and fraudulent land dealings, the administration soon went bankrupt with no money to maintain their levees, let alone build new ones (Vileisis 1997).

\section{E. Technology and a new era for drainage}

As the war progressed, flooding continued and drainage projects failed. And in1869, there became less land protected from flood waters than had been in 1854 (Harrison 1951). And in 1872, the commissioner of the GLO declared the swampland grants a failure. The floods of the late 1850s and the civil war had left the drainage districts broke and their levees in disrepair (Weaver 1964). It is easy to blame the boards of commissioners for the failure of the grant 
program, but the single most significant factor responsible for the failure was that the engineering technology just had not existed yet to make wetland drainage a profitable enterprise. This would change in the last quarter of the century as the industrial revolution led to the large scale mechanization of the entire American economy, and perhaps the most important piece was the steam-powered engine. Steam-powered machines like dredges, mill saws, bulldozers, and ditch-diggers were soon altering landscapes on enormous scales.

It is worth noting that the original swampland grants were not a complete disaster. Although they never realized their intended goals of draining swamps and creating more accessible, developable, and cultivable land, the grants were a critical first step toward those goals in the larger trajectory of American wetland reclamation. The grants also forced engineers and legislators to break new ground in thinking about how to control these landscapes both physically and politically. The swampland grants were the first iteration of an ongoing trial and error process in wetland management - they tried and failed, but they would soon return with bigger and better tools.

The first technological innovation that changed wetland drainage potential was tiling. Advances in ceramic production technology facilitated the use of u-shaped tiles (Fig. 5) that, when inverted on one another and buried underground, functioned like perforated pipe, draining saturated soils to a ditch outlet. This

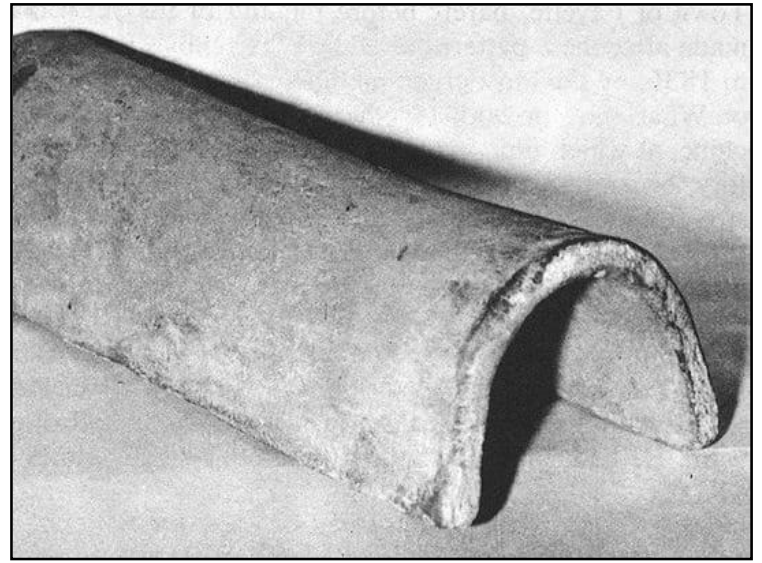

Fig. 5: Ceramic drainage tiles used to shunt water away from saturated soils revolutionized land drainage in the nineteenth century. 
technology was invented and used in Scotland in the early nineteenth century, but implemented in 1835 by Scottish immigrant farmer John Johnston in Geneva, New York by the Erie Canal (Weaver 1964). He imported plans for tiles and originally had them all produced by hand, then by a crude tile-molding machine. The tiles were then set into hand-dug ditches, making the process too expensive for large scale implementation. But by 1851 , Johnston had laid sixteen miles of tiled ditches on his land and while most people thought he was crazy, the number of believers was growing with his own land a testament to the effectiveness of tiles (Weaver 1964). A new tile machine was imported from England and production costs were cut in half, and within a decade, there were twelve new tile manufacturers within a ten mile radius of Johnston's farm. With the popularity of tiling sky-rocketing in the 1860s, the technology spread rapidly across the Midwestern and Southern states, and with steam-powered tile machines pumping out two thousand miles of drain tiles annually, they only got cheaper and more accessible for farmers (Beauchamp 1987). To compound the benefit of technology in tile production, ditch-digging went from hand-dug to horse-drawn machines in the 1850 s, steam-powered in 1892, and gasoline-powered in 1908. Technology was rapidly changing the face of wetland drainage, and therefore wetlands themselves (Weaver 1964).

Until this point, tiled ditches primarily benefited the farmers and landowners in draining their wet fields, but those ditches had to terminate in some sort of public drainage outlet, usually a canal or river. The innovation of steam powered dredges and excavators in the late 1890s dramatically changed this public end of drainage. Suddenly, massive amounts of material could be moved by a couple people operating a dredge (Fig. 6) or excavator, revolutionizing levee and canal building but also river navigation. For the first time dredges could scoop sediments from 
the bottom of rivers and lakes to excavate the channel, deepening it for ship passage or to effectively increase the channel capacity for flood control. The latter being the priority for public drainage projects, dredges and excavators would be the most important piece of technology for drainage districts for the first two decades of the twentieth century, the peak of drainage district formation, levee building, and subsequent wetland drainage and development (Prince 1997).

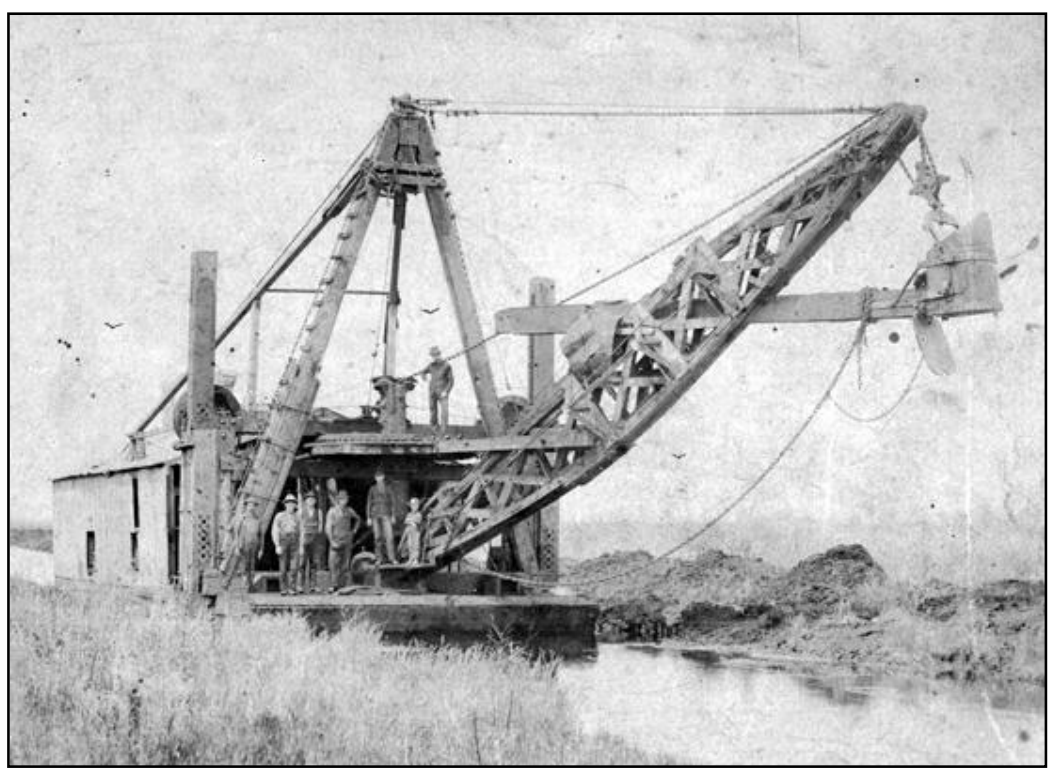

Fig. 6: Early steam-powered dredge

\section{F. Evolution of the drainage district}

As farmers found a way to drain their land with tiles, they now looked for a public drainage outlet. The drainage districts of the 1850 s had been abandoned in the early 1870 s and categorized as a legislative failure. The districts as a concept would essentially lay inactive for the next decade while technology progressed and spread throughout the country. This was a critical dormant period for the districts as it gave them a chance to develop more organically, as 
a response to the need for a public drainage outlet. Because the cost of building such drainage outlets was still too high for an average individual landowner to finance, communities of farmers came together for large-scale projects (Prince 1997). The existing laws did not allow landowners to organize and build these drainage projects on their own, so states passed new statutes that made room for what would become the modern incarnation of the drainage district. The biggest change that these statutes included was that they allowed drainage districts to tax landowners in order to pay for drainage projects and maintenance. They also gave districts the right to use eminent domain to acquire property for their projects, granted that their projects "outweigh the costs and serve public health, welfare, and utility" (McCorvie and Lant 1993, 36).

This time, however, since most of the land was privately owned, the laws were passed but the districts were not established until farmers in a given watershed and community assembled and petitioned for a district (McCorvie and Lant 1993). State by state, the country gradually passed these laws allowing the formation of drainage districts with few variations between states. Oregon was an early adopter, passing their drainage law in 1868, and was just the third state to do so behind Michigan and Ohio. By 1900, drainage districts had been widely accepted, as twelve more states passed this drainage legislation between 1870 and 1900, as land value of drained lands often rose nearly five hundred percent (Williams 1993).

The first three decades of the twentieth century were the peak of drainage district formation and activity. Sixty percent of the total drained land in the country had been drained between 1900 and 1919 (Pavelis 1987). The economy was booming during this era as the climate shifted into a wetter than average cycle for over a decade and farm prices rose. Twentythree more states would pass drainage legislation by 1930, and the 1920 census reported that 
drainage districts accounted for over sixty-six million acres of poorly-drained land (Pavelis 1987). The success of drainage districts began with technological innovation, but it was only realized with the new laws that allowed communities of farmers and landowners to organize, plan, raise revenue, and hire the engineers to accomplish the drainage.

\section{H. Ducks vs. Dredges: U.S. drainage policy through the 1950s}

The federal government was not completely out of the drainage market during the boom era of the districts. The Reclamation Act of 1902 granted some land reclamation power back to the federal government, whereas the Swampland Act had largely transferred the power to reclaim land from the national to the state and local level. The Reclamation Act created the Bureau of Reclamation housed in the Department of Agriculture (USDA), and was responsible for administering land reclamation projects, mostly dam-building, and initially only to investigate some regulatory aspects of wetland drainage, such as alkali damage due to irrigation seepage (Vileisis 1997). Two years later, the Bureau of Agricultural Engineering (BAE), also in the USDA, assumed responsibility for all things related to agricultural drainage (Beauchamp 1987).

While the federal government was actively working to drain wetlands on a large scale, a law was passed that would later prove to be instrumental in the federal protection of wetlands as bird habitat. The Migratory Bird Act of 1913 superseded states' rights and gave the federal government primary jurisdiction over migratory birds. Wetlands serve a vital role for migratory birds, as they provide expansive shallow sloughs and lakes with food and space for large flocks (Bean 1977). With federal jurisdiction over migratory birds, President Wilson signed the 
Migratory Bird Treaty with Canada in 1916. This would later require the government to preserve wetland bird habitat in order to uphold treaty obligations when wetlands were fragmented and destroyed by way of drainage (Trefethan 1975).

During the late 1920s and 1930s, drainage districts and their projects took a hit with the busting economy. Drainage districts found themselves without a tax base as landowners could not pay their bills, and so drainage projects were slowed if not altogether abandoned due to lack of funding (Pavelis 1987). Then in 1935, congress approved drainage and irrigation districts to receive assistance from the Reconstruction Finance Corporation (RFC) to help fund operations. The RFC was an independent federal agency created in 1932 to support lending to state and local governments, banks, railroads, mortgage associations, and other businesses. The RFC is largely considered a success, lending a cumulative total of two billion dollars in its twenty-five year existence, most of which was successfully repaid. And for drainage districts it was a godsend, allowing districts who were particularly struggling in twenty-six states to continue operations when they may have otherwise not been able to (O'neill 2006).

Similarly, the Civilian Conservation Corps (CCC) was another way drainage districts benefited from New Deal legislation (Fig. 7). In 1935, the BAE became responsible for forty-six CCC camps working on state-led drainage projects. The CCC provided essential free labor for many drainage districts building flood control projects, and in turn, the districts put a lot of people to work building levees that would serve the cities through flood risk reduction (Beauchamp 1987). These and other programs run by the federal and state governments allowed drainage projects to continue despite the economic downturn (Vileisis 1997) 
Pemberton 35

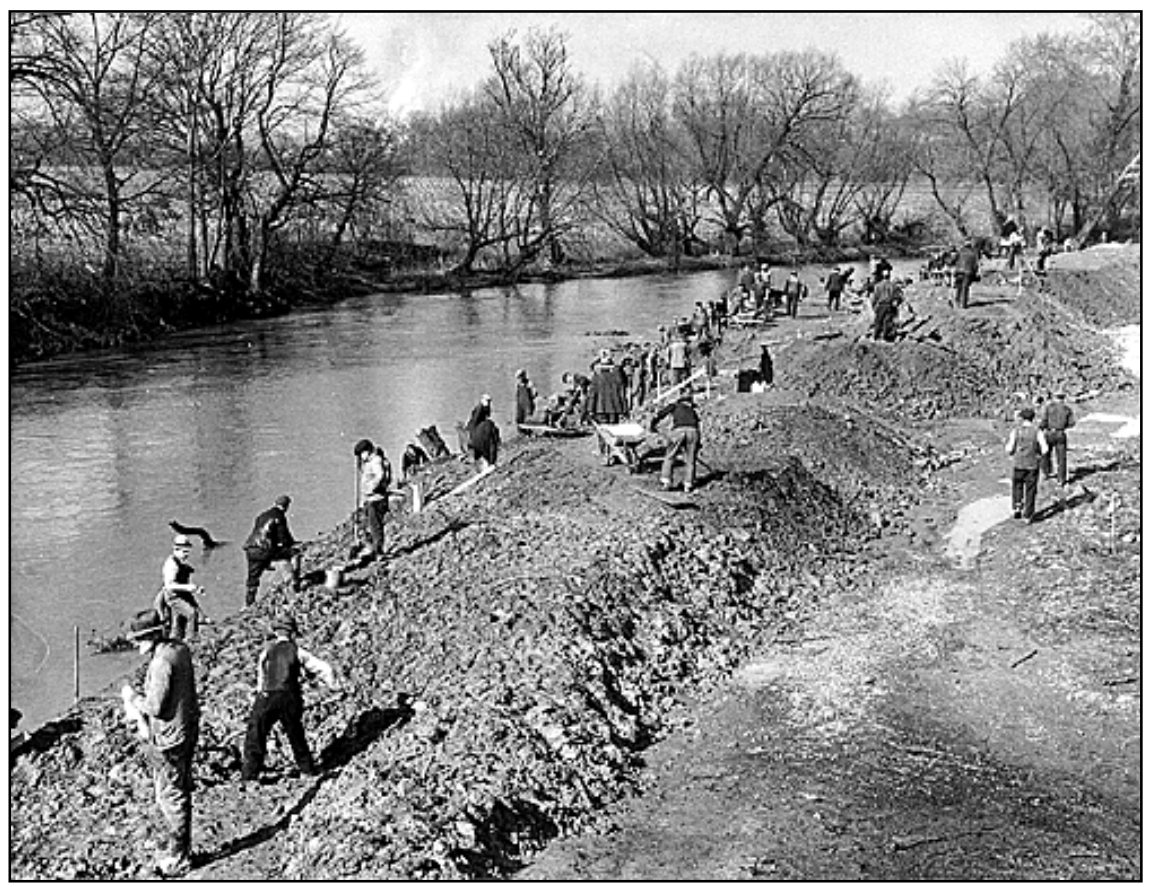

Fig. 7: WPA crews building a levee in York, PA (March, 1936)

But by the 1930s, the negative effects of drainage on wildlife were beginning to be more well-known (Fig. 8). The depression led people to hunt and fish for food, often ignoring bag limits, which then led to significant declines in many wetland species, but especially waterfowl (Kallman 1987). As a result, President Franklin Roosevelt created a special Committee on Wildlife Restoration which established Wildlife Refuges as a means of restoring habitat for waterfowl. With little to no money available for land acquisition, the Migratory Bird Hunting Stamp Act of 1934 authorized the sale of $\$ 1$ stamps to raise money for refuge acquisition (Kallman 1987). This was the first program that raised funds for refuges, but the stamps alone were not enough. Over the next several years, Congress passed laws that ensured hunting fees 
and firearm and munitions taxes were allocated to refuges, raising more money. Additionally, clubs like Ducks Unlimited and More Game Birds in America worked to fill the gaps of state and federal funding (Kallman 1987). These citizen groups were primarily composed of waterfowl hunters who experienced the declining wetland conditions through their hobby and sought to better wetland habitat, albeit in self-interest. A healthier wetland ecosystem supports more and healthier waterfowl, which means there's more and better quality waterfowl to hunt and eat. Groups like these are important to the history of conservation because they typically have considerable resources to employ towards lobbying, conservation projects, and land acquisition (Tori et al 2002; Geist, Mahoney, and Organ 2001).

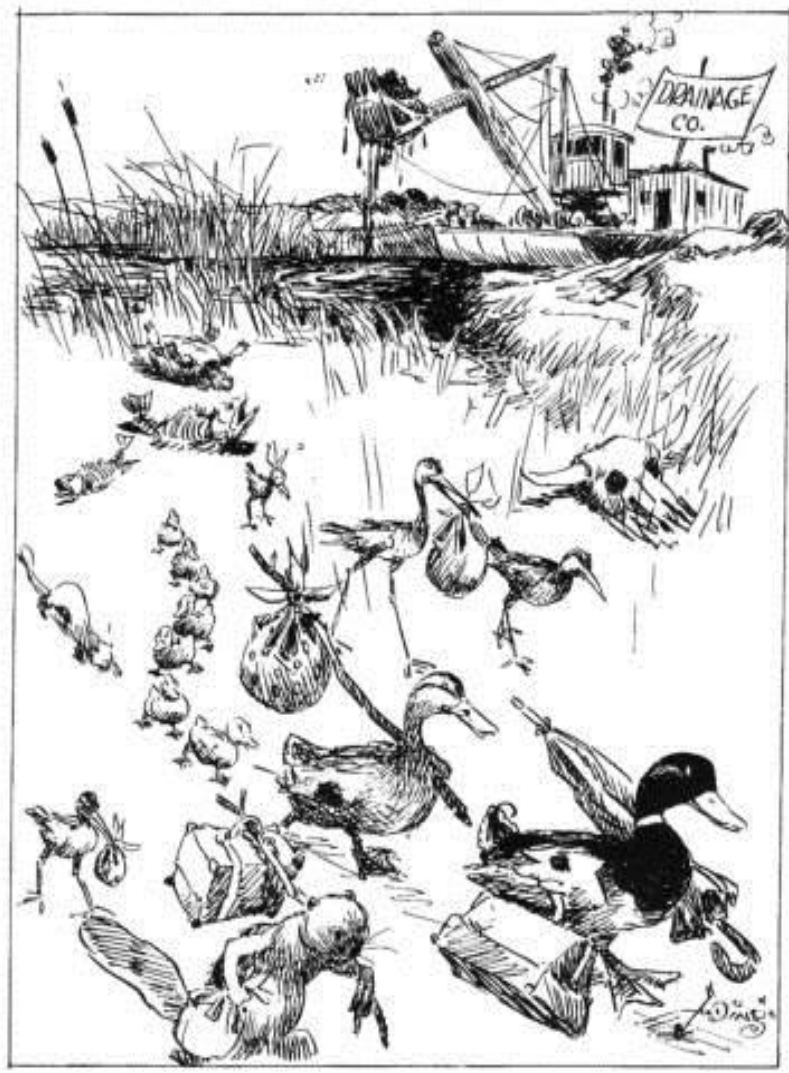

Drying Up Wild Life

Fig. 8: Darling, Jay N. Drying Up Wildlife. 1937. Editorial cartoon. http://lib.uiowa.edu/collguides/?MSC0170 
After the war, with soldiers returning home and the economy in high gear, the federal government increased drainage assistance programs like the USDA-administed Agriculture Conservation Program and the Soil Conservation Service's technical assistance program, offering free engineering assistance for new drainage projects (Errington 1957). Draining wetlands was still considered to be "conserving" the agricultural integrity of the of the soil, and so the federal government pushed drainage hard.

In the early 1950s, using duck stamp revenue, the Fish and Wildlife Service began collecting survey data on wetlands to track the quantity and quality of migratory bird habitat across the country. The survey was published in 1956 and detailed an estimated loss of forty-five million acres of native wetland habitat to "other uses" (Shaw and Fredine 1956). In 1958, Congress responded by approving the Wetlands Easement Program, also funded by duck stamp money, to protect important privately owned waterfowl breeding areas, and recommending changes to USDA regulations in subsidizing farm drainage. The USDA failed to make regulatory changes until 1963 with the passing of the Agricultural Appropriations Act that prohibited the use of federal funds for cost sharing and technical assistance to drain all inland freshwater wetlands (Kallman 1987).

Federally subsidized wetland drainage ended because habitat for migratory and game birds had been severely compromised, making the Migratory Bird Act of 1913 one of the most important pieces of legislation for the conservation of wetlands. Environmental conservation across the board, not just wetland conservation, was gaining traction in the late 1950s and into the 1960s. In the same era as Carson's Silent Spring (1962), Errington wrote Of Marshes and Men (1957) which spoke out against the drainage and development that was destroying wetland 
ecosystems across the country. Leopold's "Marshland Elegy” (1948), like Errington (1957), stemmed from the loss of Midwestern wetlands, and was written ten years earlier, mourning the fragile state of the crane in Wisconsin wetlands. These works were important contributions to the shift in perception of wetlands, as they helped to construct the idea of wetlands as a precious landscape in the American mind (Prince 1997). Americans were changing their attitude toward wetlands, and the environmental laws of the 1960s and 1970s would eventually become the cornerstone of wetland management in the twenty-first century.

\section{Environmental legislation}

Three monumental environmental laws were created in the late 1960s and 1970s that provided the tools to attack private and public projects that were considered to be harmful to the environment: the National Environmental Policy Act, Clean Water Act, and Endangered Species Act. The federal government didn't have the resources to enforce these laws on a wide scale, so citizen groups evolved as the de facto watchdog for projects that violated these laws, a dynamic that has become the very structure of the U.S. environmental protection program (Vileisis 1997). Despite this "all stick and no carrot" approach, citizen groups have had considerable success employing these laws to discourage further loss of wetlands.

\section{National Environmental Policy Act}

In 1969, Congress passed the National Environmental Policy Act (NEPA), requiring all federal agencies to evaluate the environmental impacts of their projects before work began in an environmental impact statement. A comment period was built into the approval process for 
citizen groups and other agencies to voice their concerns about the project. This was important because just like Ducks Unlimited and others had done thirty years prior, citizen groups now had a forum and a role built into the approval process.

\section{Clean Water Act}

In 1972, as public awareness of pollution and especially water pollution reached its zenith, the Federal Water Pollution Control Act was passed, more commonly known as the Clean Water Act (CWA). To curb pollution, this law was created to regulate discharge into almost any waterway in the country. Under Section 404, the law transferred ownership of all wetlands to the Army Corps of Engineers (USACE), who are responsible for managing the nation's navigable channels. Because of their history and obligation to maintain shipping channels, controversy ensued over whether the USACE wetlands were beholden to the same regulations under the CWA. Citizen groups used litigation to strong-arm the USACE into adopting the CWA regulations, which they did in 1975 (Blumm and Zahela 1989; Stine 1983).

\section{Endangered Species Act}

Passed in 1973, the Endangered Species Act (ESA) was created to protect species from going extinct. What made this law powerful, however, was that it protected the endangered species' habitat from destruction, and wetlands provide critical habitat to many endangered species (Nelson 1985). The effect of this law meant that federal agencies and others had to accommodate endangered species habitat 
Prioritizing wetlands in the 1980s and 1990s

During the 1970s, the field of wetland science grew considerably. Conferences and professional organizations of wetland scientists gained nationwide acceptance. In 1974, the Fish and Wildlife Service started the National Wetlands Inventory (NWI), a project aimed at updating the FWS wetlands survey from the 1950s. Their results were published in 1983, revealing that over nine million acres of wetlands had been lost in twenty years, and $87 \%$ were accounted for by agriculture (Tiner 1984).

Just as the results of the first wetlands inventory had stoked federal action by way of ending drainage projects, so did the NWI. In 1986, the Emergency Wetlands Resources Act (EWRA) was approved to address the wetlands crisis. The law focused on acquisition of wetlands; paying landowners for their land avoided having to regulate their activity Funding came from an extension to the Wetlands Loan Act, which allowed the FWS to borrow against future duck stamp revenue. Additionally, EWRA required the NWI to publish a new survey every ten years to keep a closer eye on the status of wetlands in the U.S (Prince 1997).

Good things kept coming for wetlands in the 1980s. The 1985 Food Securities Act, also called the "Farm Bill" and deemed "Swampbuster," eliminated subsides for farmers who "busted" up wetlands to farm them. This effectively addressed the ongoing budget crisis of the farm subsidy program and the hemorrhaging of wetland habitat by discouraging wetland drainage with the threat of subsidy loss. Unfortunately, however, enforcement proved difficult. The Farm Bill was reauthorized in 1990, adding the Wetlands Reserve Program (changed to the Agricultural Conservation Easement in the 2014 reauthorization), which pays landowners to restore their land back to a natural wetland (Vileisis 1997). 
In 1991, President George Bush instituted the "no net loss" policy, the product of a year and a half long National Wetlands Policy Forum. The forum consisted of twenty representatives from a divergent array of often competing interests in wetlands (e.g. Environmental Protection Agency, Army Corps of Engineers, National Association of Homebuilders), and was organized to come up with a wetlands policy that they could all agree on. The result was no net loss, which then presidential candidate George Bush adopted as part of his campaign platform (Babcock 1990). No net loss meant that no wetlands could be lost from any proposed project. So, naturally, the debate began over how to define a wetland. Through several iterations of definitions from several different agencies, exhaustive debate, and continued regulatory confusion over what constitutes a wetland and how it should be accounted for, political stalemate set in. Bush's term ended before the No Net Loss wetland policy he had championed during his campaign could really take effect (Lewis 2001).

In 1993, President Clinton ended the divisive debate over federal wetlands policy. He reestablished no net loss of wetlands and threw a bone to all of its opponents, offering exemptions to the CWA for fifty-three million acres of converted wetlands, endorsing mitigation banking (compensatory offsite wetland conservation) for projects that violate the CWA, and continued support for wetlands restoration (Lewis 2001). Clinton's No Net Loss policy was considered a diplomatic move since all sides benefited slightly and no one group was satisfied (Blumm 1993; Lewis 2001; Vileisis 1997).

Debate over wetlands, how to account for them, and how to conserve them has persisted since the Swampland Act of 1849. Competing priorities of citizens, states, and federal agencies complicate the process of forming an overarching wetland policy that addresses conservation 
and the economic use of the landscape. The Swampbuster was reauthorized in 2014 with no changes to the regulations, despite continued known violation (GAO 2003). Wetland losses continue, albeit at a slowed pace (Fig. 9), and the debate over the effectiveness of mitigation banking as a conservation measure continues as well (Levrel 2017).

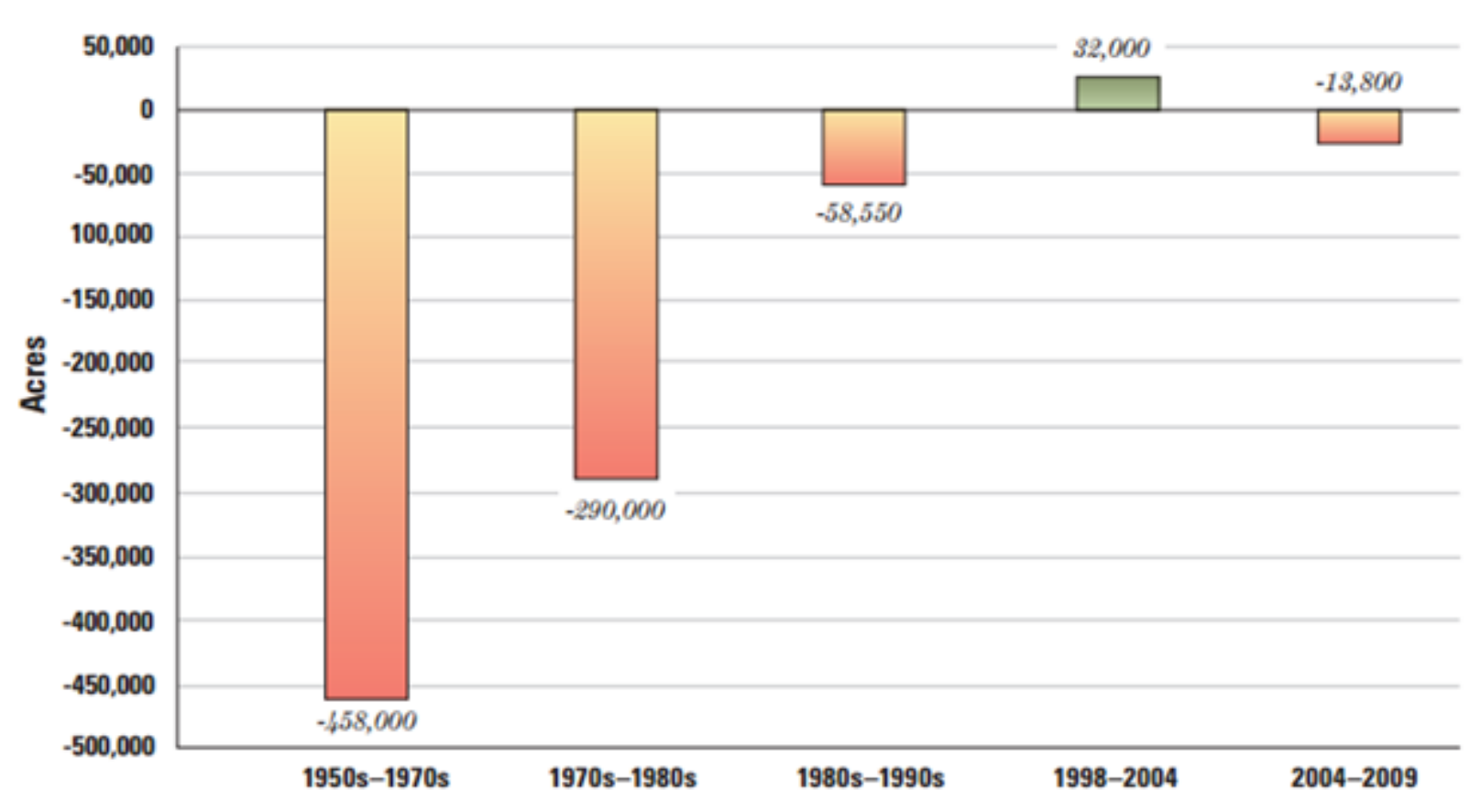

Fig. 9: Average annual wetland loss since the first wetland survey in the 1950s

The rate of wetland depletion at the national level is one way to measure shifting attitudes toward wetlands over time. At this scale, changes in federal wetland management correlate with a reduction in the rate of wetland depletion nationwide (Fig. 9). But what about the local scale? Can changes in these wetland landscapes at the city-wide scale be observed to correlate with shifting attitudes? Using the Columbia Slough as a case study, I examine how the landscape has evolved to reflect these cultural values. 


\section{The Columbia Slough}

The first human use of the Slough was by American Indians. In 1805, the Lewis and Clark Corps of Discovery came down the Columbia River and explored the Columbia Slough, noting the Ne-cha-co-lee village of the Multnomah Chinook tribe (Thwaites 2001). The village occupied the present day site of Blue Lake Park and served as a seasonal village for hunting, fishing, and other cultural celebrations (Metro 2015).

The Hudson Bay Company and North West Company trapped extensively in the Slough until 1820, shipping the furs back east and even as far as England (Fairview 1992). The rest of the nineteenth century saw the settling of the Slough, with agriculture comprising most of the land use throughout the watershed. Until the twentieth century when the Multnomah County Drainage District would be established, each farm was in charge of their own drainage projects, including the use of drainage tiles in parts of the watershed (Stroud 1995).

\section{A. The early $20^{\text {th }}$ century Slough}

While wetland drainage progressed in the rest of the country, Portland found itself poised to take full advantage of the new technology and government programs to expand their developable real estate into the nearby Columbia Slough watershed. The Great Flood of 1894 caused extensive damage in downtown Portland and the lower Willamette areas. This instilled Portlanders with a fear of flooding that would resonate throughout the region with the construction of the Columbia Slough levee system, thereby dramatically altering the landscape for the foreseeable future (MacColl 1979).

John Charles Olmsted, step brother of the renowned Frederik Law Olmsted who designed 
Central Park and many other exalted public spaces in the country, submitted a parks plan to the City of Portland in 1903. The plan included an interconnected network of greenspace across the entire city, and highlighted an expansive meadow park in the Columbia Slough. Unfortunately, the plan was not accepted and the park was never built (Orloff 2004).

In 1907, the watershed began experiencing the first of what would be a long history of industrial use. The Seattle Portland and Spokane Railroad built their rail line through the Slough adjacent to Smith and Bybee Lakes. Stockyards and meat packing plants soon opened in the watershed following the lucrative transportation route (MacColl 1988). Transportation is one of the most important concepts of how the Columbia Slough has become the regional economic center it is today. The flat flood-forged landscape has made it highly conducive to transportation by rail, ship, automobile, and air. Accessibility, geographic situation, and location on the periphery of Portland makes the Slough very attractive for companies to locate their facilitiesespecially industrial businesses that manufacture and move goods.

\section{B. Columbia Slough drainage districts are established}

The creation of the drainage districts in the Slough begins with James O. Elrod, a farmer turned real estate developer and capitalist who moved to Portland in 1905. After his arrival, Elrod quickly made friends with local bankers and businessmen, whom he called upon when proposing the Multnomah Drainage District in 1918 (MacColl 1979). Elrod saw the success of the expansive Sun Dial Ranch in the eastern part of the watershed, which supplied many of the local towns and communities with beef and pork products (Fairview 1992). To accomplish this, the Sun Dial Ranch had diked and drained much of its land to raise stock. Elrod's friends were 
affiliated with the United States Employment Service, a national organization dedicated to finding employment for returning servicemen, and he thought that by establishing this drainage district, he could open up 8,000 acres of farmland to put unemployed servicemen to work after the war ended (MacColl 1979). In 1918, Elrod's proposal for the district to the State of Oregon included his stated intentions as such:

(T)he sole object of the proposed district improvement is to make productive by creating conditions favorable to its full use for agricultural purposes... Such an improvement will be an aid to the development of the enclosed and adjacent lands for industrial and commercial purposes and can in no way interfere with such development. (MCDD 1918)

Elrod made the argument for "taking advantage of the higher land in the east of their district" to build a canal with a gate at the western end of their district, and making it possible to simply purge their section of the Slough by pumping water through the canal back to the Columbia River. By doing this, Elrod thought water quality would improve by allowing fresh water to flow through the Slough (MCDD 1918). The City Canal (now called the Peninsula Canal) was completed in 1919 and would ultimately be considered a failure and rendered inoperable in 1948 after the Vanport Flood ravaged the entire levee system. Damming the Slough at the west end of the drainage district trapped industrial waste and water quality worsened as the intended purging through the canal never worked as planned (Stroud 1995). The canal now sits unused as a long and narrow lake between the Slough and the river, inaccessible due to the tall steep dike walls on both sides. 
The Multnomah Drainage District ${ }^{2}$ (MDD) was established in 1918, establishing Elrod as president. He immediately went to work gaining approval from the Port of Portland and the Army Corps of Engineers to build two dams on the Columbia Slough as he outlined in his proposal letter (MacColl 1979). Beyond approval, Elrod needed to raise funds for his project. In his proposal, he quotes the project at a cost of thirty-five cents per acre to "maximize the utility of the land for agriculture and industrial development" (MCDD 1918). Fortunately, one year prior, the Oregon Legislature created the Irrigation and Drainage Securities Commission to certify irrigation and drainage bonds as legal instruments for trust funds. In 1919, the MDD raised $\$ 600,000$ through bond sales for its construction projects. Additionally, Elrod drew on his co-investors in the North Pacific Lumber Company and received federal funds by way of the Sinnot Bill ${ }^{3}$, which allocated $\$ 113$ million to reclamation projects (MacColl 1979).

By 1921, the Portland Telegram reported that the MDD has already generated $\$ 3.5$ million for the county and its inhabitants, and that farm production was up by more than 50 percent (MacColl 1979). But agricultural land sales began to taper off in the mid-1920s and all but ceased during the depression. The 1920s brought with it other industrial development in the Slough. Lumber and wood products companies, such as the Kenton Shingle Company and Kenwood Lumber Company opened in the lower stretch of the Slough where tugboats would move log rafts in and out of the Slough where the companies operated from. By the 1930s and 1940s, as many as eleven lumber and shingle companies would be operating in the watershed. (Fig10)

\footnotetext{
${ }^{2}$ The name of the Multnomah Drainage District was later changed to "Multnomah County Drainage District" (MCDD) at a date unknown. The two are used interchangeably in this paper.

${ }^{3}$ Representative Nicholas Sinnott from The Dalles was a long-time friend of the Elrod family (MacColl 1979).
} 


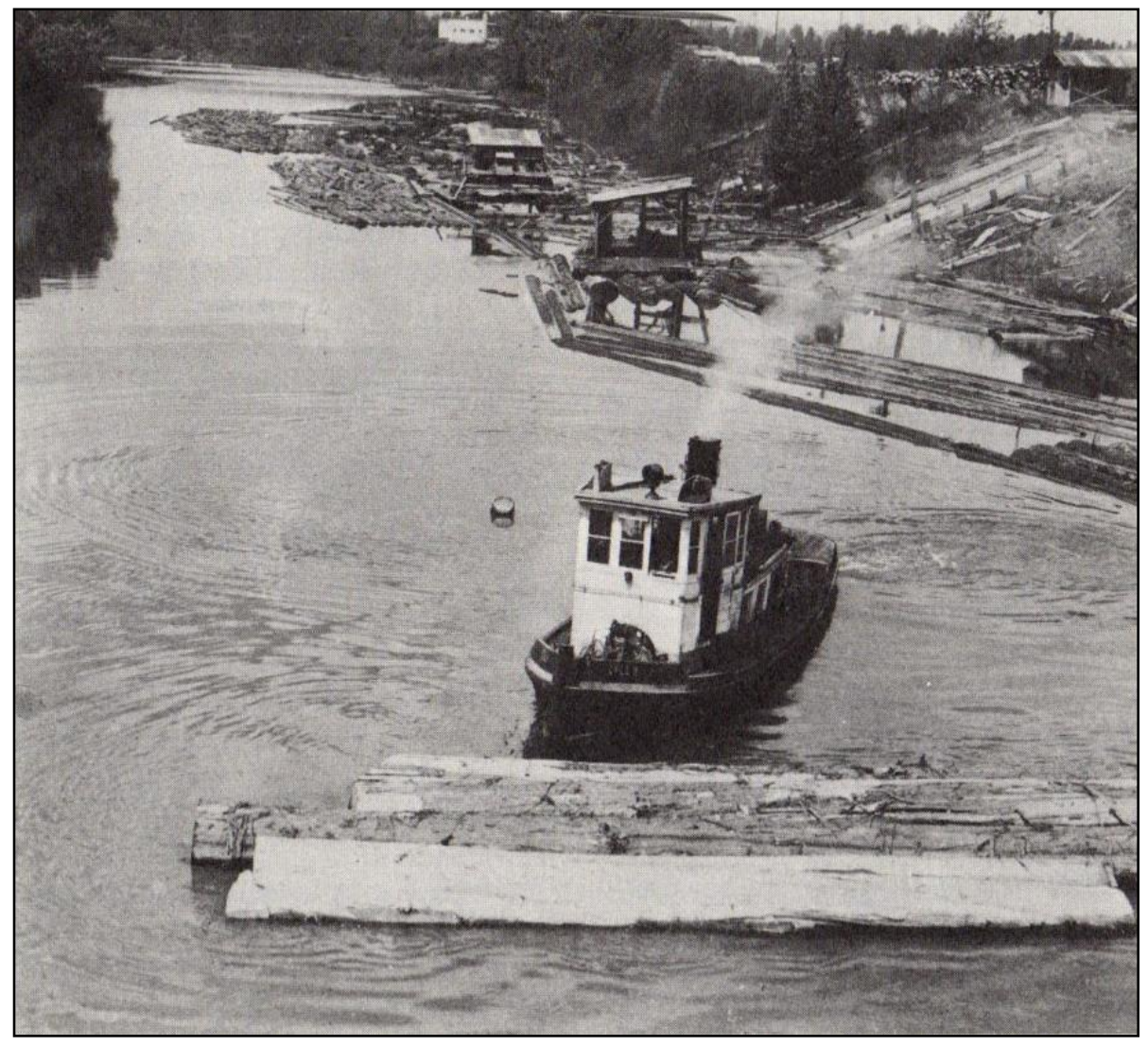

Fig. 10: Commercial log raft in the Slough around 1940.

During the depression, the MDD received help from the Reconstruction Finance Corporation loans that were created as part of Roosevelt's New Deal legislation to help reclamation projects stay afloat (MacColl 1979). By 1935, 7,000 acres were planted in crops and nearly 900 farmers were living within the MDD boundaries (Oregon 1935). This was the peak of farming in the Slough, as World War II would have two different effects on the landscape: industrialization and housing.

Shipping and industrial development ramped up during the war years, putting the MDD in premium position to drain its remaining wetlands and capitalize on its accessibility, situation, 
and location. Along with industry, nearby housing for employees was needed, so communities like the 650-acre Vanport were built to support the growing demand for affordable housing near factories. In the mid-1930s, the Port of Portland acquired 700 acres of farmland in the middle of the MDD for construction of a new international airport (Lansing 2003). With that, came warehouses and distribution facilities to transfer goods throughout the region. Through all of this, the landscape was changing. What developers like Elrod initially saw as farmland potential in the Slough, they now saw greater, more lucrative potential in industrial and commercial development.

After the war, much of Elrod's drainage district began transitioning from farmland to commercial, recreational, and residential developments. Golf courses and subdivisions were replacing large tracts of farmland; Elrod himself owned two private golf courses in the Slough (MacColl1979). The view of the Sloughscape was shifting, but this change was not due to changing cultural values, but just simply improving economic potential. The respective conversions of wetland to farmland and farmland to industrial, commercial, and residential land are driven by the same function: economic potential. The values of citizens and those in power over the Slough still saw the landscape as something to be used and employed as a means to make money.

\section{Testing the levees}

Flood control is considered as one of the primary reasons levees are built. In their century of existence, the MCDD levees have been tested four times, each event serving as a knick point for change in modifying and improving the levee system; unfortunately, the levees have only 
passed three of those four tests. The first true test came in June of 1933, fifteen years after their construction, when the Columbia River rose thirty-two feet during a late spring flood (Maben 1987). The levees successfully held back the flood waters and their permanence in the collective public mind only solidified. The next major flood event would not be such a success. Another fifteen years later, the Vanport Flood would blow out a levee and erase an entire town from the map.

Vanport

Several historians and other social scientists have written about the 1948 flooding and subsequent destruction of the city of Vanport, the nation's largest wartime housing development, as it is considered to be one of Oregon's biggest natural disasters (McGregor 2003; McElderry 1998; Maben 1987; Rivera and Miller 2007). The story of Vanport has become a legendary tale of environmental injustice and catastrophic urban planning, caused by the failure of a MCDD levee during a spring high water event in 1948 (Stroud 1999). The town was built to help quell Portland's housing crisis caused by the major influx of workers immigrating to Portland for the many available jobs in the shipyards. Unfortunately, Vanport was built on 650 acres north of Denver Avenue and east of the Northern Pacific Rail line levee, the present day site of Delta Park, Portland International Raceway, and Heron Lakes Golf Course. At its peak in 1944, Vanport was estimated to house 42,000 people, but population waned toward the end of the war. After the war, the resident population became increasingly African American and the town developed a reputation for housing people on welfare and high crime rates, despite the fact crime rates were not significantly different from the rest of the city of Portland (Stroud 1999). Vanport 
was thought of as a "great headache" and a "municipal monstrosity" by then Portland mayor Earl Riley, exemplifying the general attitude of many Portland residents toward Vanport (Maben 1987).

On May 30, 1948, the Columbia River rose to fifteen feet above its flood plain, contained only by its dikes, and broke through the North Pacific Railroad embankment bordering the west side of Vanport (Fig. 11). The town flooded quickly, washing away vehicles and the thin wooden apartment structures housing 18,000 people.

Fifteen people died in the flood and the entire city of Vanport was wiped from the map, being completely destroyed and never rebuilt, displacing those 18,000 people, most of whom were minorities (McGregor 2003). The Vanport Flood became another chapter of the larger history of racial prejudice in Portland (Stroud 1999), but only because a levee was breached. This tragedy did not bring pause for city

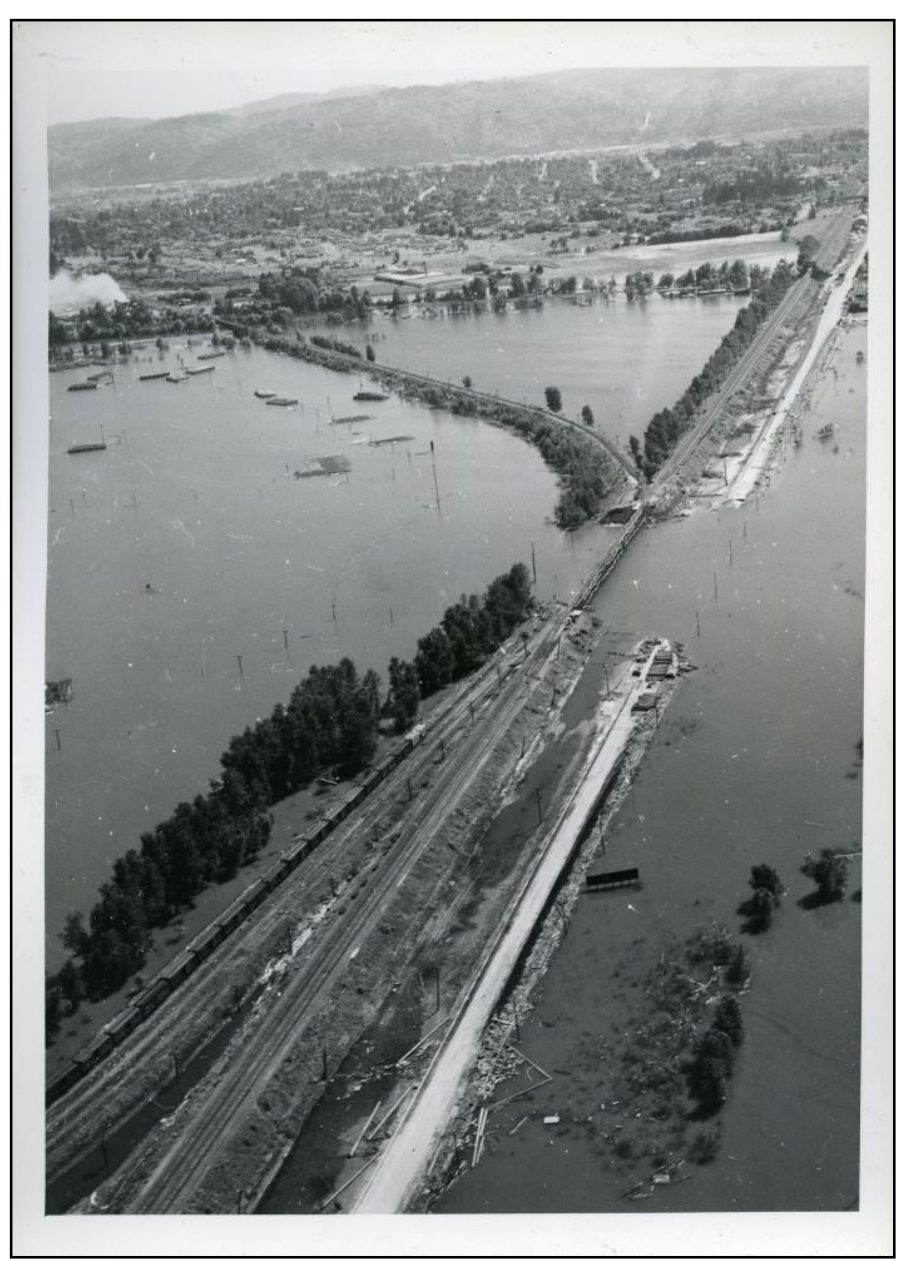

Fig. 11: Aerial photo of flooded Vanport at the site of the breach (looking south toward Portland) officials to consider the risks of building in a wetland, but only encouraged them to build higher, stronger levees. After the flood, the levees were rebuilt higher and reinforced across the system, 
this time to survive a 100-year flood event (Maben 1987).

\section{4 and 1996 Floods}

Sixteen years after Vanport, the Christmas Day Flood of 1964 tested the levees once again. The flood severely damaged crops throughout the Willamette Valley as the Willamette River swelled, but the MCDD levees did their job and held back the floodwaters of the Columbia (Abbott 2001). This flood spurred the conception and construction of the mid-dike

levee at NE $142^{\text {nd }}$ Ave (MCDD 2016), which provides further flood protection by separating the middle and upper Slough . The 1996 flood caused some damage by way of erosion on many of the levees, but no major failures or levee breaches occurred to the extent they had in 1948 . However, in the same area that once housed Vanport, the levee adjacent to the Portland International Raceway experienced significant movement and emergency repairs were required to keep it from washing out (MCDD 2016). This was the closest the levees have come to breaching as they had in 1948, and to enhance the interoperability and cooperation of the four districts. After the 1996 flood the MCDD took over administration of the four districts in the Slough, citing the need for centralized administration during emergencies and cohesive operation as a single system of levees (MCDD 2016).

\section{The drained landscape becomes a regional economic center}

The growth of a place and the development of its economical or political power depend largely on its geographic situation and its accessibility (Taafe et al. 1996). Once drained, the Columbia Slough landscape became extremely accessible. Its situation at the confluence of two 
major rivers, proximity to Portland, and low relief made it an excellent place for Portland to expand its economy.

In 1891, the Oregon Legislature established the Port of Portland to create and maintain a navigable shipping channel to a depth of twenty-five feet from downtown Portland on the Willamette River, up the Columbia River to the Pacific Ocean (MacColl 1988). The Port did little in the Slough through its first eighty years of existence, as they primarily were in charge of dredging and working with the United States Army Corps of Engineers (USACE) to make sure ships could reach Portland. Portlanders soon realized that private railroads and corporations were quickly buying up all the waterfront property in town; this was concerning to people as they saw it impinging access for shipping and reducing the economic potential of the city. As a result, in 1910 citizens of Portland approved the spending of $\$ 500,000$ to purchase waterfront property for public docks. However, then Mayor Joseph Simon, who was considered to have ties with the railroad, vetoed the ordinance. But voters came right back, using a new initiative process, to approve \$2.5 million (\$60.3 million in 2016 dollars) and create a Commission of Public Docks, side-stepping the Mayor and breaking up the railroad monopoly. The commission opened their first dock, called Terminal 1, in 1913 (Lansing 2003).

\section{Shipping Terminals}

Five more terminals would be built over the next seventy years, with Terminal 1 demolished in 1932 to make way for the St. John's Bridge, and Terminal 3 at Washington Street being similarly demolished for the Marquam Bridge in the 1960s (MacColl 1979). Terminals 5 and 6, built in the 1970s, fall within the Columbia Slough watershed and are associated with the 
Rivergate Industrial District, a Port property adjacent to the terminals. The Port's terminals are immensely important to the economy of Portland and the surrounding region as they are necessary for all of the overseas importing and exporting of the area. They allow ships to offload their cargo and send it anywhere in the region by plane, train, truck, and other ships going up the Willamette and Columbia rivers. The Slough's geography as a flat flood plain allows this regional economic center to function, making it an ideal location to receive goods by many modes of transportation and then distribute them throughout the region.

\section{Airports}

The Port of Portland would become a big player in the Columbia Slough over the next hundred years, merging with the Commission of Public Docks in 1970, and establishing several assets in the watershed that have become the framework for the economic development that dominates Columbia Slough land use today. The Port completed the city's first airport in 1927 on Swan Island after acquiring it in 1921. The island was a true island initially and the main channel of the Willamette River went along the east side of the island, but with the use of the new dredging technology, the Port immediately began dredging the west side of the island, shifting the river's main channel and allowing the island to be connected to the east bank (MacCol 1979). By the mid-1930s, larger passenger and cargo aircraft demanded longer landing strips than what Swan Island could offer, so the Port began construction on the Portland-Columbia Airport, later renamed as the Portland International Airport, located squarely in the center of the then newlyleveed Columbia Slough watershed (Abbott 2001). Using money from the city of Portland, the federal WPA program, and the Port, the airport was completed in 1940. It was built on 700 acres 
bordering the Columbia River to the north and the Columbia Slough to the south, and was expanded in 1959 by one runway and a terminal, and then doubled in size in 1977 to roughly its current state (MacColl 1979). In 1942, the Port also purchased the 284-acre Troutdale Airport located toward the eastern end of the watershed; however it is a much smaller airport serving flight schools, light cargo, and private aviators.

\section{Other Properties}

Airports have been an important piece of the Port's portfolio, providing air transportation for the entire Portland Metro area as Oregon's largest and the Northwest's second largest airport. But the Port's activity in the Slough reaches further yet beyond airports and marine terminals. Other Port properties include the Rivergate Industrial District, the Portland International Center, Cascade Station, Air Cargo, the Gresham Vista Business Park and the Troutdale-Reynolds Industrial Park. These properties account for 4,000 total acres of commercial and industrial development near the largest transportation arteries in the region, including the Union Pacific and BNSF railroads, Portland International Airport, two marine terminals, and three interstate freeways in I-5, I-205, and I-84. These properties are owned by the Port and are leased to businesses wishing to operate in close proximity to shipping and transportation centers (Port of Portland 2013).

Not only is the Port a major regional economic center by way of its capacity to receive and distribute goods throughout the region, transport people to all parts of the world, and provide spaces for businesses to operate in close proximity to these transportation resources, but it is also directly and indirectly responsible for over 40,000 jobs located in the Columbia Slough 
watershed. Together, these factors make the Slough a highly valuable economic asset to the city of Portland and the region. The Port alone is directly and indirectly responsible for billions of dollars changing hands in the watershed between imports and exports, goods transportation and distribution, human transportation, businesses manufacturing and selling products and materials, and jobs (Port of Portland 2013).

\section{E. The natural landscape in an industrial sanctuary}

The naturally flat topography of the flood plain that is the Columbia Slough has had two effects on the story of the human use of its landscape. Firstly, because the Slough's terrain is flat and stretches a considerable distance from east to west, it is highly conducive to being a transportation thoroughfare by many modes. Excellent transportation and close proximity to the Portland metropolitan area makes it an ideal location for mineral and materials manufacturing facilities, warehouses, storage facilities, distribution centers, and other businesses (Abbott 2001). These types of operations created a lot of pollution that would go unchecked until the 1970s with the passing of the Clean Water Act, and because the Slough's topography is so flat and the MCDD's levees and dikes prevent the seasonal floods that would usually flush the system, the effluent from these facilities would stay put and would not flow downstream. Hence, the Slough's waterways became highly polluted soon after industrial use of the landscape began, with stockyards and lumbermills discharging their waste directly into the Slough (Abbot 2001). The ecological health of the Slough would continue this negative trend until the late 1980s and early 1990s when the City of Portland began implementing certain policies and regulations to protect the "natural and manmade" features of the Columbia Slough. This would all come to a 
head in 1991 with the closure of the St. John's Landfill, a landmark victory for the St. Johns community and for the broader efforts of citizens working to preserve natural space throughout the Columbia Slough watershed.

\section{The first legally protected natural areas in the Slough}

In 1987, the City of Portland developed the Columbia South Shore Plan District, which created zones within the Columbia Slough watershed to "protect, conserve, enhance, restore, and maintain significant natural and manmade features of public value, including river corridors, streams, lakes and islands, domestic water supply watersheds, flood water storage areas, natural shorelines and unique vegetation, wildlife and fish habitats, significant geological features..." (Portland 1987). This was the first time the government officially designated any space in the Slough to be protected, be it natural or manmade, from a city zoning standpoint. The following year, the city developed environmental protection and conservation zones for areas with important natural resources. This was still mostly a zoning regulation in that environmental protection areas were not to be developed but conservation areas could have some development, provided the proper measures were taken to control pollution (Portland 1987).

These were important first steps in preserving the future of what little natural space the Slough had, but the City had no intention of ever slowing or reducing the economic hub that the Slough had become. In 1989, the Portland Development Commission established the Airport Way Urban Renewal Area as an industrial sanctuary, making development and economic growth its highest priority while setting the goal to create 20,000 new jobs over the next twenty years (Portland 1987). Industrial use of the Slough was not being displaced, it was being preserved. 
The difference was that the City was now recognizing the Slough as not just a ditch for effluent, but a natural space, however small.

In 1990, the City developed the Columbia South Shore Natural Resources Management Plan (NRMP). The plan would be revised multiple times over the next few years by citizen appeal for the twenty-five foot conservation easement along the length of the Slough to be expanded to fifty feet. The change would be adopted in 1993 as progress toward environmental reclamation in the Slough moved forward. The NRMP also called for protection of various small wetlands, lakes, and water bodies throughout the watershed, restricting outfalls and other potentially pollutant point-sources surrounding them (Portland 1990). This same year, the Smith and Bybee Lakes Natural Area was officially established as the first protected natural area in the Slough as a part of the Oregon Natural Areas Program. These events set the scene for the closing of the landfill in St. Johns in 1991, which bordered the Slough and the Smith and Bybee wetlands.

\section{St. Johns Landfill}

In 1940, the banks of Bybee Lake were designated as the site for the next municipal dump. The St. Johns Landfill (Fig. 2), ten minutes due north of downtown Portland would serve north Portland, St. Johns, Kenton, and the other surrounding towns and neighborhoods for the next fifty years, collecting primarily domestic waste but also industrial waste from a pesticide manufacturing facility from 1958-1962 (Speirs 2012). While in operation, the landfill received an estimated fourteen million tons of waste before its closure in 1991 (Metro 2017). Serving an extensive region that included residential and industrial waste, the landfill drew heavy truck 
traffic and resulted in trash illegally dumped along the road, under bridges, and in the neighboring Columbia Slough (Spears 2012). These negative side effects of the St. John's Landfill drew the ire of Jacob Benshoof, a local activist who grew up in St. Johns, who would become the leader of the movement to close the dump. Backed by the St. Johns Development Corporation, Benshoof made several enemies in the county, city, and regional government. In addition to its basic service to the region as a landfill, the St. John's Landfill generated considerable revenue for the city, making it a particularly valuable public asset.

Benshoof and the St. John's Development Corporation found that the landfill was in violation of the 1899 Rivers and Harbors Act, a federal law that prohibited the long term storage of waste near waterways. The St. John's Landfill in this case bordered the Smith and Bybee Wetlands and the Columbia Slough, putting it in direct violation of the Rivers and Harbors Act. So along with a few other local organizations, the St. John's Development Corporation sued the City of Portland and won, sealing the fate of the St. John's Landfill (Speirs 2012).

The regional governing body, Metro, took over the operations of St. John's Landfill in 1980 and full ownership in 1990

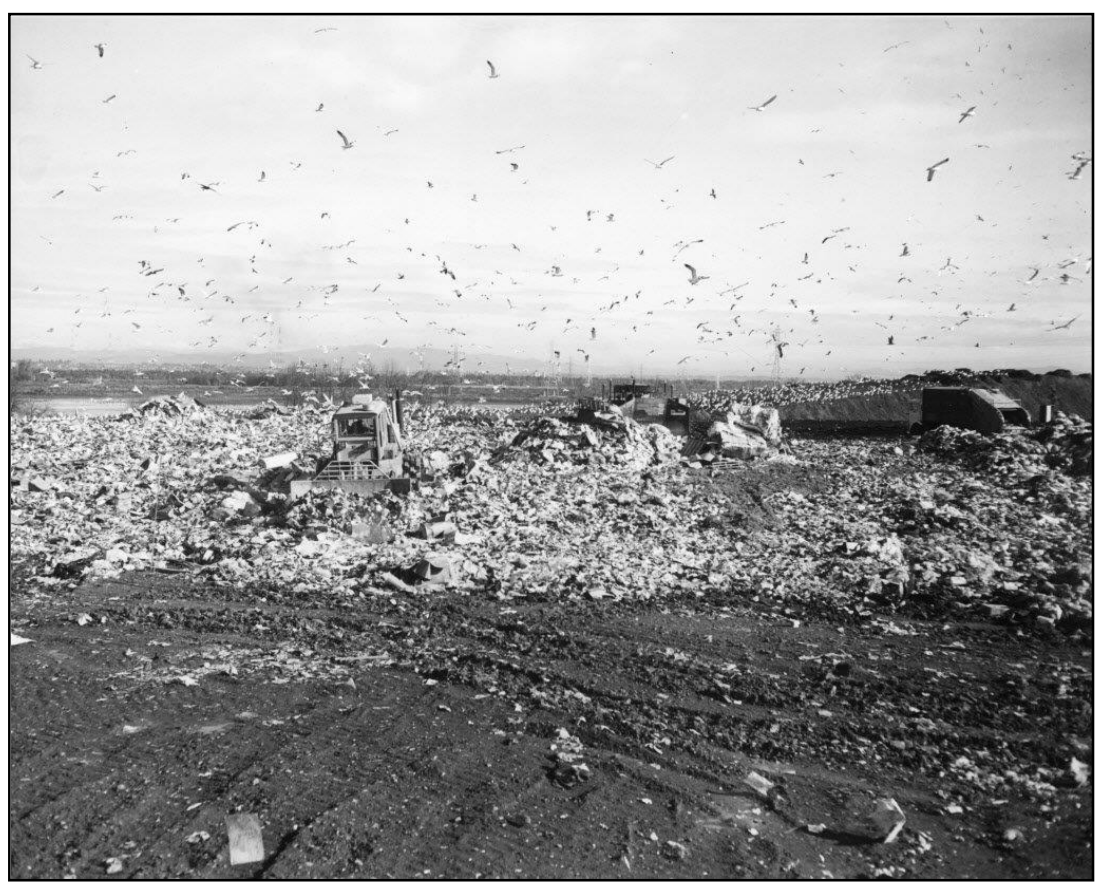

Fig. 12: St Johns Landill, 1972 
as it assumed the responsibility for permanently closing the landfill. As a result of the landfill lawsuit, Metro was tasked with developing a solution to contain the landfill, and prevent contaminants from leaching into the Slough and lakes. The result was a $\$ 36$ million containment system that encapsulates the entire 230-acre landfill (Metro 2017). Completed in 1996, the surface of the contained landfill was planted with native prairie plants and given the classification as a nature preserve with no public access. Amazingly, the dump-top prairie has been remarkably successful, harboring tons of species including deer, beaver, coyote, and prairie birds.

The containment system is continuously monitored by the Oregon Department of Environmental Quality, with erosion being the primary concern for the integrity of the containment system (Fitzgibbon 1999). Additionally, the methane produced by the landfill, which was originally burned off on site, is sold to a local cement company who uses it as fuel for their lime kilns, creating a small revenue stream for Metro. Altogether, the closure of the SJL has been a success (Mortenson 2011).

With the SJL closed, the momentum of the Slough's environmental advocates continued through the early 1990s. In December 1991, the nonprofit, Northwest Environmental Advocates (NEA), brought a suit against the City of Portland for allowing combined sewer overflows (CSOs) to discharge raw sewage into the Slough during heavy rain events. The suit called out the CSO system for violating the Clean Water Act and demanded that the City make the changes necessary to comply with water quality standards (Speirs 2012). To comply, the City set off on a \$1.4 billion, twenty-year long project called simply "The Big Pipe Project," which made the sewer pipes bigger so they overflowed into the Columbia Slough and Willamette River less 
frequently (State of Oregon 2010).

In 1993, NEA spearheaded a community-based campaign against the City and other state government organizations over the toxicity of fish caught in the Slough. They made several press releases and led efforts to educate the public about the dangers of consuming fish caught in the Slough, a public health concern that had not been addressed by government agencies. NEA found that the dangers of consuming Slough fish disproportionately affected minorities because more minorities lived in close proximity to and fished in the Slough, raising questions around environmental racism and feigned ignorance to the risks affecting a predominantly minority population in Slough anglers (Stroud 1999). Again, this public attention raised awareness of the unique environmental issues in the Slough.

The year 1993 continued to be productive for conservation in the Slough. The NRMP changes were rewritten and rolled into the new Natural Resources Protection Plan (NRPP) that included the fifty-foot conservation easement along the length of the Slough and around many of the lakes and small water bodies in the watershed (Portland 1993). Additionally, that same year the Columbia Slough Watershed Council (CSWC) was established to provide a forum for citizens, businesses, activists, government agencies, landowners, and recreationists to come together in support of the watershed as a whole. The CSWC has since been instrumental in educating the public, especially children, about the watershed, how it works hydrologically and ecologically.

More educational programs would be established by the City of Portland in 1996 through the Columbia Slough Revitalization Program, which was a City-led program funded by a $\$ 10$ million grant from the EPA. The program used the money to fund projects in education/ outreach 
and mitigation to help the Slough improve its poor ecological health. Such projects included scientific research studying sediments and water quality, landowner incentive programs, revegetation and habitat conservation, and educational projects including angler outreach, environmental educators in k-12 schools, storm drain stenciling, community and school-based tours, classes, field trips, and informational kiosks throughout the community. The grant took the momentum that started in the late 1980s and gained traction around the turn of the decade with the SJL closure and the NEA lawsuits and awareness campaigns, launching the Slough into a new era of natural resource management and environmental education.

\section{Current efforts changing the Sloughscape}

In 2005, the City of Portland (2005) created the Portland Watershed Management Plan (PWMP) with the focus of improving the ecological health of five urban watersheds, one of which was the Columbia Slough. The stated purpose of the plan was to "improve watershed conditions," and within the plan they detail goals that support this purpose, such as restoring riparian habitat, regulating stormwater outfalls, and protecting native species (Portland 2005). The effects of this plan and other projects in the Slough aimed at restoring ecological health have already begun to change the landscape of the watershed.

In 1999, anadromous salmonids were listed under the Endangered Species Act, and two years later they were found in the lower Slough. This led to increased monitoring of water quality and multi-agency habitat restoration projects like the Columbia Slough Confluence Habitat Enhancement Project, which, completed in 2010, increased and improved habitat for all wetland species in the lower Slough (CSWC 2013). Another project owned by the City with the 
collaboration of several agencies is the Mason Flats Wetland Enhancement Project, located at NE Mason and Airport Way in the Big Four Corners Natural Area, was completed in 2013, restoring more wetland habitat. Even the USACE has undertaken habitat restoration projects in the Slough. In 2003, the 1135 Restoration Project was completed, enhancing riparian habitat and removing five culverts along seven miles of the middle and upper stretches of the Slough. These are just a few examples of the larger capital projects led by government agencies to help improve watershed conditions (Portland 2015). Many other smaller scale projects and frequent work parties organized by the CSWC have made great strides in managing invasive species and removing trash and debris from the watershed (CSWC 2013).

In 2015, as a part of the long-term watershed monitoring, the Bureau of Environmental Services began issuing annual environmental health report cards for watersheds and parts of watersheds under the PWMP. The Slough's grades were as follows, hydrology: B-; water quality: B-; habitat: D-; and fish and wildlife: F (Portland 2015). No real conclusions can be drawn on these grades independently, but they may prove to be a useful tracking tool as time goes on and more projects are completed.

Aside from the physical health of the watershed, funding from the PWMP and others like it is being used for watershed education (Portland 2005; CSWC 2013), which indirectly benefits the natural landscape by cultivating a well-informed culture (Hibbard and Lupie 2006). A culture that understands and appreciates their home watershed promotes conservation and changes the landscape in a more abstract way than the other programs and projects. The assumption is that people who are educated about their watershed will make choices in their daily lives and possibly vote for representatives and issues that benefit the environment. Education is the long- 
term plan for creating a healthier natural landscape.

\section{Conclusion}

The Columbia Slough exists today as a landscape of seemingly incongruous neighbors with a long history of conflicting agendas. Protected natural areas replete with wildlife in rich wetland ecosystems adjoin cement factories with billowing smokestacks, enormous warehouses with constant freight traffic, and giant shopping centers, parking lots, and freeways. The levees built by the drainage district in the early twentieth century opened the door for the developers and the industrialists to take advantage of the Slough's premium accessibility, location, and situation. Most people traveling in the watershed are not aware of the Slough or the wildlife that lurks just out of sight. Development in the Slough has explicitly tried to hide its natural elements from view, creating a landscape dominated by concrete and asphalt. From early logging in the watershed by Portland's forefathers to the drainage culture of the early twentieth century to the toxic polluters that followed the levees, the Slough has had a long history of declining environmental health. However, because of increased efforts to create a public natural amenity in the watershed, changes in the landscape have taken place. As the perspective of wetlands has shifted over the past century, so has the Slough landscape by way of new policies and programs. Lewis writes that "Our human landscape is our unwitting autobiography, reflecting our tastes, our values, our aspirations, and even our fears in tangible, visible form" $(1979,12)$. The tastes, values, and aspirations revealed in the Columbia Slough landscape are those that have consistently prioritized utility and economy over nature. This is evident through the history of wetland policy, draining and farming wetlands were federally subsidized activities until the 
1950s. This converted millions of acres across of wetlands across the country into farms, displacing wildlife and native vegetation. In the case where these drained wetlands provided excellent accessibility, situation, and location near an urban center, such as the Columbia Slough, they were developed into industrialized economic hubs that dominate the landscape. But whether farm or economic hub, pollution became an issue, and starting around the 1960s, new federal policies aimed at protecting the environment were established. The effects of these policies began changing in the Columbia Slough landscape in the 1980s with the establishment of conservation zones, regulated effluent, and public natural space. Today, aided strongly by the Portland Watershed Management Plan for the Columbia Slough (2005), there is a concerted effort to create a healthier watershed for wildlife, plants, and humans alike.

Looking at the whole landscape together, and reading it in its historical context, it is evident that cultural values toward the Slough have changed. As wetland policies have shifted at the federal and local levels, the landscape has reflected these changing values with more space for the natural wetland landscape to function. However, the efforts to restore the natural landscape are not to achieve some paradigm shift where natural capital overtakes economic capital; the Slough is a not a landscape that will be an expansive natural wetland again in the near future. Instead, these wild enclaves amidst an industrialized landscape serve the community as a park, creating a space that is used for recreation, wildlife viewing, and education. This has created the highly integrated physical landscape of built and natural environments seen in the Slough today: an otherwise economic landscape punctuated by wild enclaves that is treasured simultaneously for its wildness and industry. 


\section{Bibliography}

Abbott, Carl. 1999. Footprints and Pathways: The Urban Imprint on the Pacific Northwest.In Northwest Lands, Northwest Peoples: Readings in Environmental History, ed. D. D. Goble, D and P. W. Hirt, 111-124. Seattle: University of Washington Press.

Abbott, Carl. 2001. Greater Portland: Urban life and landscape in the Pacific Northwest. Philadelphia: University of Pennsylvania Press.

Babcock, Hope. 1990. "Federal wetlands regulatory policy: up to its ears in alligators."Pace Environmental Law Review 8 (2): 307.

Barnes, Trevor J., and James S. Duncan. 1988. Writing worlds: discourse, text and metaphor in the representation of landscape. London: Routledge.

Barney, William L. 1987. The passage of the republic: an interdisciplinary history of nineteenthcentury America. Lexington: DC Heath \& Company.

Beauchamp, Keith H. 1987. "A history of drainage and drainage methods." In Farm Drainage in the United States: History, Status, and Prospects, United States Department of Agriculture 1455: 13-29.

Bean, Michael J. 1977. Evolution of national wildlife law [Wildlife protection and conservation]. No. NP-22037 Environmental Law Institute. Washington, DC.

Bishop, Ellen Morris. 2003. In search of ancient Oregon: a geological and natural history. Portland: Timber Press.

Blumm, Michael C. 1993. "The Clinton Wetlands Plan: No Net Gain in Wetlands Protection." Journal of Land Use \& Environmental Law 9 (2): 203-242.

Blumm, Michael C., and D. Bernard Zaleha. 1989. "Federal wetlands protection under the Clean Water Act: regulatory ambivalence, intergovernmental tension, and a call for reform." University of Colorado Law Review 60: 695.

Bogue, Margaret Beattie 1951. "The Swamp Land Act and wet land utilization in Illinois, 18501890." Agricultural History 25 (4): 169-180.

- 1959. "Patterns from the sod: Land use and tenure in the Grand Prairie, 1850-1900." Patterns from the sod: Land use and tenure in the Grand Prairie, 1850-1900. Illinois State Historical Society. Springfield.

Bunce, Michael. 1994. The countryside ideal: Anglo-American images of landscape. London: 
Routledge.

Carson, Rachel. 1962. Silent spring. Boston: Houghton Mifflin Harcourt.

Christy, John A., and Edward R. Alverson. 2011. "Historical vegetation of the Willamette Valley, Oregon, circa 1850." Northwest Science 85 (2): 93-107.

Clean Water Act of 1972, 33 U.S.C. $§ 1251$ et seq. (2002). Retrieved from

http://epw.senate.gov/water.pdf

Columbia Slough Watershed Council. 2013. "Columbia Slough Projects and Programs: 20032013.” https://www.columbiaSlough.org/our_watershed/action_plan. Accessed on 4/28/2017.

Congressional Globe 1850. $31^{\text {st }}$ Congress, $1^{\text {st }}$ Session. (Found in Bogue 1951, 170)

Cosgrove, Denis. 1985. "Prospect, perspective and the evolution of the landscape idea." Transactions of the Institute of British Geographers 10 (1): 45-62.

. 1998. Social formation and symbolic landscape. 2nd ed. Madison: University of Wisconsin Press.

Cosgrove, Denis, and Stephen Daniels 1988. The iconography of landscape: essays on the symbolic representation, design and use of past environment. Cambridge: Cambridge University Press.

Cowdrey, Albert E. 1977. "Land's end: A history of the New Orleans District." US Army Corps of Engineers, and Its Lifelong Battle with the Lower Mississippi and Other Rivers Wending Their Way to the Se, 96. New Orleans: U.S. Army Corps of Engineers.

Cronon, William. 1983. Changes in the land: Indians, colonists, and the ecology of New England. New York: Hill and Wang.

Danbom, David B. 1991. "Romantic agrarianism in twentieth-century America." Agricultural History 65 (4): 1-12.

Denevan, William M. 1970. "Aboriginal Drained-Field Cultivation in the Americas PreColumbian reclamation of wet lands was widespread in the savannas and highlands of Latin America." Science 169 (3946): 647-654.

Denevan, William M. 1992. "The pristine myth: the landscape of the Americas in 1492." Annals of the Association of American Geographers 82 (3): 369-385.

Duncan, James. 1995. "Landscape geography, 1993-94." Progress in Human Geography 19 (3): 
414-422.

Duncan, James, and Nancy Duncan. 1988. "(Re) reading the landscape." Environment and Planning Development: Society and Space 6 (2): 117-126.

Ellet, Charles. 1852. Senate Exec. Doc., $32^{\text {nd }}$ Cong., $1^{\text {st }}$ Sess. "Report on the Overflows of the Delta of the Mississippi". 45, 97.

Errington, Paul. 1957. Of men and marshes. Iowa City: University of Iowa Press.

Fairview, City of. 1992. "Fairview Cultural Resource Inventory and Historical Context.". http://www.oregon.gov/oprd/HCD/OHC/docs/multnomah_fairview_historiccontext.pdf. Accessed on 5/6/17.

Fitzgibbon, Joe 1999. "Erosion is Nibbling away at St. John's Landfill.” The Oregonian, Portland, OR. August 16, 1999.

GAO, US. 2003. "Agricultural Conservation: USDA Needs to Better Ensure Protection of Highly Erodible Cropland and Wetlands. Report to the Ranking Democratic Member, Committee on Agriculture." Nutrition, and Forestry, US Senate (2003). Found in Sibbing, Julie M.

"Nowhere near no-net-loss." National Wildlife Federation. http://www. nwf. org/wildlife/pdfs/NowhereNearNoNetLoss. pdf Reviewed: June (2008).

Geist, Valerius, Shane P. Mahoney, and J. F. Organ. 2001. "Why Hunting Has Defined the North American Model of Wildlife Conservation." Transactions of the North American Wildlife and Natural Resources Conference 66: 175-185.

Harrison, Robert W. 1951. Swamp Land Reclamation in Louisiana, 1849-1879: A Study of Flood Control and Land Drainage in Louisiana Under the Swamp Land Grant of 1849. Washington: US Bureau of Agricultural Economics.

Hewes, Leslie, and Phillip E. Frandson. 1952."Occupying the wet prairie: The role of artificial drainage in Story County, Iowa." Annals of the Association of American Geographers 42 (1): 2450 .

Hibbard, Michael, and Susan Lurie. 2006. "Some community socio-economic benefits of watershed councils: A case study from Oregon." Journal of environmental planning and management 49 (6): 891-908.

Houck, Michael C., and Mary Jane Cody, eds. 2000. Wild in the City: A Guide to Portland's Natural Areas. Portland: Oregon Historical Society Press. 
Johnson, Stephen, Gerald W. Haslam, and Robert Dawson. 1993. The Great Central Valley: California's Heartland. Berkeley: University of California Press.

Johnston, Robert D. 1998."The myth of the harmonious city: Will Daly, Lora Little, and the hidden face of Progressive-era Portland." Portland: Oregon Historical Quarterly 99 (3): 248-297.

Kallman, Harmon. 1987. "Restoring America's wildlife, 1937-1987: the first 50 years of the Federal Aid in Wildlife Restoration (Pittman-Robertson) Act." Washington: US Fish and Wildlife Service.

Lang, William L.1999. "From where we are standing: The sense of place and environmental history." In Northwest Lands, Northwest Peoples: Readings in Environmental History, ed. D. D. Goble, D and P. W. Hirt, 79-94. Seattle: University of Washington Press.

Lansing, Jewel. 2003. Portland: People, Politics, and Power: 1851-2001. Corvallis: Oregon State University Press.

Lefebvre, Henri 1991. The production of space. Oxford: Blackwell.

Leopold, Aldo, and Stewart L. Udall. A sand county almanac. 1948. New York: Oxford University Press.

Lev, E., J. Fugate, M. P. Hayes, D. Smith, L. Wilson, and R. Wissemann. 1994. "The biota of Smith and Bybee Lakes Management Area". Portland: Metro.

Levrel, Harold, Pierre Scemama, and Anne-Charlotte Vaissière. 2017. "Should We Be Wary of Mitigation Banking? Evidence Regarding the Risks Associated with this Wetland Offset Arrangement in Florida." Ecological Economics 135: 136-149.

Lewis, Gene D. 1968. Charles Ellet, Jr., the Engineer as Individualist, 1810-1862. Urbana: University of Illinois Press.

Lewis, Peirce F. 1979."Axioms for reading the landscape." The interpretation of ordinary landscapes 23: 167-187.

Lewis Jr, William M. 2001.Wetlands explained: wetland science, policy, and politics in America. Oxford: Oxford University Press.

Maben, Manly. 1987. Vanport. Portland: Oregon Historical Society Press.

MacColl, E. Kimbark. 1979. The growth of a city: power and politics in Portland, Oregon, 1915-1950. Athens: Georgian Press. 
MacColl, E. Kimbark, and Harry H. Stein. 1988. Merchants, money, and power: the Portland establishment, 1843-1913. Athens: Georgian Press.

Malone, Linda A. 1993. "Reflections on the Jeffersonian Ideal of an Agrarian Democracy and the Emergence of an Agricultural and Environmental Ethic in the 1990 Farm Bill." Stanford Environmental Law Journal 12 (3): 3-49.

McCorvie, Mary R., and Christopher L. Lant. 1993. "Drainage district formation and the loss of Midwestern wetlands, 1850-1930." Agricultural History 67(4): 13-39.

MCDD. 1918. "Closing of Columbia Slough." Letter to Colonel George A. Zinn, United States Army Corps of Engineers, Portland, OR. 12 Jan. 1918. Center for Columba River History. Web. 3 July 2016.

MCDD. 2016. "Floods of the Columbia River Corridor." Story map. https://floodprotection.maps.arcgis.com/apps/MapJournal/index.html?appid=6c768aaaeb834c18 b99c25750cdfb1c9. Accessed on 5/7/17.

McElderry, Stuart. 1998. "Vanport Conspiracy Rumors and Social Relations in Portland, 19401950." Portland: Oregon Historical Quarterly 99(2): 134-163.

McGregor, Michael. 2003. "The Vanport Flood \& Racial Change in Portland." The Oregon History Project. Portland: Oregon Historical Society.

Meinig, Donald William. 1968. Great Columbia Plain; a historical geography, 1805-1910. Seattle: University of Washington Press.

- 1979. "The beholding eye: Ten versions of the same scene." The interpretation of ordinary landscapes: Geographical essays, 33-48. New York: Oxford University Press.

- 1995. The shaping of America: a geographical perspective on 500 years of history. Vol. 2. New Haven: Yale University Press.

Metro. 2015. "Blue Lake Regional Park Historic Resource Plan” 2015. http://www.oregonmetro.gov/sites/default/files/A\%20history\%20of\%20Blue\%20Lake\%20Regio nal\%20Park.pdf. Accessed on 5/6/17

2017. "St. Johns Landfill.” Website: http://www.oregonmetro.gov/st-johns-landfill. Accessed on 5/7/2017.

Miller, David. 1989.Dark Eden: The swamp in nineteenth-century American culture. New York: Cambridge University Press. 
Mitchell, Don. 2000. Cultural geography: A critical introduction. Oxford: Blackwell.

- 2008. "New axioms for reading the landscape: paying attention to political economy and social justice." Political economies of landscape change: 29-50.

Mortenson, Eric. 2011. "Portland's defunct St. Johns Landfill, once a stinking dump, rises from the trash into a meadow suited to lure larks." The Oregonian. Portland, OR. March 21, 2011.

Nelson, Jana. 1989. "Agriculture, wetlands, and endangered species: The Food Security Act of 1985." Endangered Species Technical Bulletin 14(5): 1-6. (Found in Vileisis 1997)

O'Neill, Karen M. 2006. Rivers by design: state power and the origins of US flood control. Durham, NC: Duke University Press.

Oregon, State of. 1935. "Biennial report of the State Reclamation Commission for the period. Salem, Or: State Printing Department". (Found in MacColl 1979).

Oregon, State of. 2010. "Portland Combined Sewer Overflow Management Fact Sheet". . Department of Environmental Quality..

Orloff, Chet. 2004. "Maintaining Eden: John Charles Olmsted and the Portland Park System." Yearbook of the Association of Pacific Coast Geographers 66 (1): 114-119.

Orr, Elizabeth L. and William N. Orr. 1999. Geology of Oregon. Dubuque, IA: Kendall Hunt Publishing Company.

Pavelis, George A., ed. 1987 In Farm Drainage in the United States: History, Status, and Prospects, United States Department of Agriculture Economic Research Service 1455: 13-29.

Port of Portland. 2013. "Properties." Brochure. https://popcdn.azureedge.net/pdfs/Prp_Portfolio.pdf. Accessed on 5/7/17.

Portland, City of. 1987. Columbia South Shore Plan District. Portland: Bureau of Planning

— 1993. "Columbia South Shore Natural Resource Protection Plan.” Portland: Bureau of Environmental Services. https://www.portlandoregon.gov/bps/article/58934

- 2005. "Chapter 7: Stream Flow and Hydrology Characterization" In Columbia Slough Watershed Characterization. Portland: Bureau of Environmental Services.

_ 2005. "Portland Watershed Management Plan". Portland: Bureau of Environmental Services." 
—. 2007. “Columbia Slough Watershed Long Term Monitoring Plan.” Portland: Bureau of Environmental Services.

_. 2015. "2015 Columbia Slough Report Card". Portland: Bureau of Environmental Services. https://www.portlandoregon.gov/bes/article/526631. (2015). Accessed on 8/1/2016.

Prince, Hugh. 1997. Wetlands of the American Midwest: a historical geography of changing attitudes. Chicago: University of Chicago Press.

Profita, Cassandra.2012. "How Toxic Is This Catfish From Columbia Slough?" Ecotrope. Oregon Public Broadcasting, 13 June 2012. Web. 22 Apr. 2017.

<http://www.opb.org/news/blog/ecotrope/how-toxic-is-this-catfish-from-columbia-Slough/>.

Pyne, Stephen J. 1982. Fire in America. A cultural history of wildland and rural fire. Princeton: Princeton University Press.

Rivera, Jason David, and DeMond Shondell Miller. 2007. "Continually neglected: Situating natural disasters in the African American experience." Journal of Black Studies 37(4):502-522.

Robbins, William G. 1999. "Willamette Eden: The Ambiguous Legacy." Northwest Lands, Northwest Peoples: Readings in Environmental History, ed. D. D. Goble, D and P. W. Hirt, 95110. Seattle: University of Washington Press.

Schein, Richard H. 1997."The place of landscape: a conceptual framework for interpreting an American scene." Annals of the Association of American Geographers 87 (4): 660-680.

Shaw, Samuel P., and C. Gordon Fredine. 1956. "Wetlands of the United States: their extent and their value to waterfowl and other wildlife". Washington: US Department of the Interior, Fish and Wildlife Service. (Found in Vileisis 1997).

Sitterson, Joseph Carlyle. 1953. Sugar country: the cane sugar industry in the South, 17531950. Lexington: University of Kentucky Press.

Speirs, Jim. 2012.“The life and times of the St. Johns Landfill.” St. Johns Review 109(25-26).

Stine, Jeffrey K. 1983. "Regulating wetlands in the 1970s: US Army Corps of Engineers and the environmental organizations." Forest \& Conservation History 27 (2): 60-75.

Strausberg, Stephen F. 1977."Indiana and the Swamp Lands Act: A Study in State Administration." The Indiana Magazine of History 73 (3): 191-203.

Stroud, Ellen. 1995. "A Slough of troubles: an environmental and social history of the Columbia 
Slough.” Masters Thesis. University of Oregon.

_. 1999. "Troubled waters in ecotopia: environmental racism in Portland, Oregon." Radical History Review 74: 65-95.

Taaffe, Edward James. 1996. Geography of transportation. Saddle River, NJ: Prentice Hall.

Terry, Russell L. 1935. “The Political Career of Solomon Weathersbee Downs”. Master's thesis, Louisiana State University. (Found in Vileisis 1997).

Thorson, T. D., S. A. Bryce, D. A. Lammers, A. J. Woods, J. M. Omernik, J. Kagan, D. E. Pater, and J. A. Comstock. 2003. "Ecoregions of Oregon" (color poster with map, descriptive text, summary tables, and photographs). Reston, VA: U.S. Geological Survey (map scale $1: 1,500,000)$.

Thwaites, Reuben Gold. 2001. Original Journals of the Lewis and Clark Expedition: Part 1 \& 2 Vol. 7. Digital Scanning Inc.

Tiner Jr, Ralph W. 1984. Wetlands of the United States: current status and recent trends. Washington, DC: United States Fish and Wildlife Service.

Tori, Gildo M., Scott McLeod, Keith McKnight, Thomas Moorman, and Frederic A. Reid. 2002. "Wetland conservation and Ducks Unlimited: Real world approaches to multispecies management." Waterbirds 25 (2): 115-121.

Trefethen, James B., and Peter Corbin. 1975. American crusade for wildlife. Winchester Press.

Tuan, Yi-Fu. 1974. Topophilia: A study of environmental perceptions, attitudes, and values. New York City: Columbia University Press.

- 1977. Space and place: The perspective of experience. Minneapolis: University of Minnesota Press.

Vileisis, Ann. 1997. Discovering the unknown landscape: a history of America's wetlands. Washington, D.C.: Island Press.

Weaver, Marion M. 1964. History of Tile Drainage in America Prior to 1900. Waterloo, NY: self-published.

White, Richard. 1995. The organic machine: The remaking of the Columbia River. London: Macmillan. 
Williams, Michael. 1993. "Agricultural impacts in Temperate Wetlands." in Wetlands: a threatened landscape. Cambridge, MA: Blackwell Publishers. 
Image References

Fig. 1: Cropsey, Jasper. Haymaking. 1853. Oil on Canvas. Saginaw Art Museum. Saginaw, MI. https://www.saginawartmuseum.org/index.php/9-collections-research/121-romantic-landscapein-america (accessed on 2/15/2017)

Fig. 2: Chapman, John Gadsby. Lake of the Dismal Swamp. 1842. Engraving. 11.5 x $19 \mathrm{~cm}$. American Antiquarian Society. Worcester, MA. https://www.nsf.gov/news/news_summ.jsp?cntn_id=118131 (accessed on 2/15/2017)

Fig. 3: Peirce, William J. Portraits of United States Senators: Solomon Weathersbee Down. Gleason's Pictorial Drawing Room Companion.1853. Wood engraving. 35 x $24 \mathrm{~cm}$. United States Senate, Washington, DC.

https://www.senate.gov/artandhistory/history/common/generic/Photo_Collection_of_the_Senate _Historical_Office.htm (accessed on 2/17/2017)

Fig. 4: Colonel Charles Ellet Jr. c.1850. Photograph. Glover Park History Museum. http://gloverparkhistory.com/estates-and-farms/clifton/charles-ellet-jr (accessed on 2/17/2017)

Fig. 5: http://www.democratandchronicle.com/story/rochester-magazine/fingerlakes/2015/05/20/drain-tiles-farmer-draining-agriculture-john-johnston-geneva-finger-lakeshistorical/27652311/

Fig. 6: Dredge on the Kankakee, Burrows Camp. 1909. Shook Collection, Northwest Indiana Genealogical Society. http://www.nwigs.org/ImageArchive/KankakeeRiver/KankakeeRiverIndiana-BurrowsCampDredge-1909-SS.jpg (accessed on 3/1/17)

Fig. 7: (Untitled). York, PA 1936. Photograph. New Deal Network archives. http://newdeal.feri.org/library/ab99.htm (accessed on 3/1/17)

Fig. 8: Darling, Jay N. Drying Up Wildlife. 1937. Editorial cartoon. http://lib.uiowa.edu/collguides/?MSC0170

Fig. 9: Dahl, T.E. 2011. Status and trends of wetlands in the conterminous United States 2004 to 2009. U.S. Department of the Interior; Fish and Wildlife Service, Washington, D.C. 40.

Fig. 10: http://www.stjohnsheritage.org/wp-content/uploads/2015/12/1940-Commercial-lografting-in-the-Columbia-Slough.jpg

Fig. 11: The dike that let the water into Vanport. May 1948. Photograph. 5" x 7". Portland State University Flood of ' 48 Collection. https://exhibits.library.pdx.edu/items/show/203 (accessed 3/4/2017) 
Pemberton 75

Fig. 12: St. John's Landfill. 1972. Photograph. Oregon Metro Archives. http://www.oregonmetro.gov/metro-archives-and-special-collections (accessed on 3/4/2017) 